\author{
UNIVERSIDADE DE SÃO PAULO \\ FACULDADE DE ZOOTECNIA E ENGENHARIA DE ALIMENTOS
}

TATIANA MARIA NOGUEIRA CHINAIT

Avaliação das barreiras aplicadas às linguiças cozidas e defumadas como investigação das causas de sua deterioração

Pirassununga / SP

2019 


\section{Avaliação das barreiras aplicadas às linguiças cozidas e defumadas como investigação das causas de sua deterioração}

(Versão Revisada)

Dissertação de Mestrado apresentado à Faculdade de Zootecnia e Engenharia de Alimentos da Universidade de São Paulo, como parte dos requisitos para obtenção do título de Mestre em Ciências do Programa de PósGraduação em Gestão e Inovação na Indústria Animal.

Área de Concentração: Gestão e Inovação na Indústria Animal

Orientadora: Profa. Dra. Marta Mitsui Kushida

Pirassununga 
Ficha catalográfica elaborada pelo

Serviço de Biblioteca e Informação, FZEA/USP, com os dados fornecidos pelo(a) autor(a)

Chinait, Tatiana Maria Nogueira

Avaliação das barreiras aplicadas às linguiças cozidas e defumadas como investigação das causas de sua deterioração / Tatiana Maria Nogueira Chinait ; orientadora Marta Mitsui Kushida. -- Pirassununga, 2019.

$92 \mathrm{f}$.

Dissertação (Mestrado - Programa de Pós-Graduação em Mestrado Profissional Gestão e Inovação na Indústria Animal) -- Faculdade de Zootecnia e Engenharia de Alimentos, Universidade de São Paulo.

1. Produtos Cárneos. 2. Tecnologia das Barreiras. 3. Segurança de Alimentos. 4. Microbiologia. 5. Shelf life. I. Kushida, Marta Mitsui, orient. II. Título. 
Avaliação das barreiras aplicadas às linguiças cozidas e defumadas como investigação das causas de sua deterioração

Dissertação de Mestrado apresentado à Faculdade de Zootecnia e Engenharia de Alimentos da Universidade de São Paulo, como parte dos requisitos para obtenção do título de Mestre em Ciências do Programa de PósGraduação em Gestão e Inovação na Indústria Animal.

Área de Concentração: Gestão e Inovação na Indústria Animal

Data de aprovação:

Banca Examinadora:

Profa. Dra. Marta Kushida - Presidente da Banca Examinadora Faculdade de Zootecnia e Engenharia de Alimentos (FZEA/USP) - Orientadora

Profa. Dra. Daniela Souza Ferreira

Faculdade de Engenharia de Alimentos (FEA/UNICAMP)

Profa. Dra. Eliana Setsuko Kamimura

Faculdade de Zootecnia e Engenharia de Alimentos (FZEA/USP)

Prof. Dr. Marco Antônio Trindade

Faculdade de Zootecnia e Engenharia de Alimentos (FZEA/USP) 
Dedico este trabalho aos meus pais, meu esposo, irmãs e sobrinhos, por serem o meu porto seguro e pela certeza de que sempre me incentivarão a ir mais longe. 


\section{AGRADECIMENTOS}

Primeiramente agradeço à Deus pelo dom da vida e por todas as oportunidades de crescimento e amadurecimento. Por permitir a realização desse trabalho e por estar sempre comigo.

Aos meus pais e José Antônio e Eliana por sempre terem me incentivado a estudar, por me ensinarem a viver com fé e a esperar o melhor da vida.

Ao meu esposo Guilherme pela paciência, compreensão, companheirismo, amizade, alegria e amor.

Às amigas, companheiras de trabalho e de estudo, Giovana, Gisele e Izabel que tornaram mais leve essa caminhada. Obrigada por dividirem comigo as angústias e alegrias, foi muito bom poder contar com vocês!

À minha orientadora Prof ${ }^{a}$ Dra Marta Mitsui Kushida por me auxiliar com todo o seu conhecimento, competência e sensibilidade. 
"Por vezes sentimos que aquilo que fazemos não é senão uma gota de água no mar. Mas o mar seria menor se lhe faltasse uma gota". Madre Teresa de Calcutá 


\section{RESUMO}

CHINAIT, T. M. N. Avaliação das barreiras aplicadas às linguiças cozidas e defumadas como investigação das causas de sua deterioração. 2019. $92 \mathrm{f}$. Dissertação (Mestrado) - Faculdade de Zootecnia e Engenharia de Alimentos, Universidade de São Paulo, Pirassununga, São Paulo, 2019.

Linguiças cozidas defumadas armazenadas a temperatura ambiente, é um produto tipicamente brasileiro, no qual são empregadas algumas barreiras para a extensão do shelf life: cozimento, defumação e embalagem à vácuo. Estudos de durabilidade comprovaram que muitas não atendem ao shelf life esperado. Na empresa estudada, somente $23 \%$ dos lotes das linguiças em estudo atenderam a 90 dias de armazenamento desejados para a indústria de alimentos e $17 \%$ dos lotes não chegaram à 45 dias. Foram realizadas avaliações microbiológicas antes do cozimento (média de 5,03 log UFC/g), após cozimento (média de 1,56 log UFC/g) e após resfriamento (média 1,54 log UFC/g) para os gomos com calibre de $40-44 \mathrm{~mm}$; comprimento $23-26 \mathrm{~cm}$; com peso variando de 260-300 gramas onde foram submetidos ao processo de cozimento e defumação por, no mínimo, 5 horas, atendendo no mínimo $71,1^{\circ} \mathrm{C}$ no centro térmico do gomo. Os parâmetros físicoquímicos também foram avaliados e atendem a legislação, com valores de aw 0,938 e pH 6,33, favoráveis ao desenvolvimento microbiológico. Também foram realizadas análises sensoriais para avaliação dos atributos sensoriais ao longo do armazenamento a temperatura ambiente.

Palavras-chave: Produtos Cárneos. Tecnologia das Barreiras. Segurança de Alimentos. Microbiologia. Shelf life. 


\begin{abstract}
CHINAIT, T. M. N. Evaluation of the hurdle applied to cooked and smoked sausages as an investigation of the causes of their deterioration. 2019. $92 \mathrm{f}$. Dissertação (Mestrado) - Faculdade de Zootecnia e Engenharia de Alimentos, Universidade de São Paulo, Pirassununga, São Paulo, 2019.
\end{abstract}

Smoked sausages stored at room temperature, is a typical Brazilian product, in which some hurdles are used to extend shelf life: cooking, smoking and vacuum packing. Durability studies have proven that many do not achieve the expected shelf life. In the studied company, only $23 \%$ of the lots of the sausages under study attended the 90 days of storage desired for the food industry and $17 \%$ of the lots did not reach 45 days. Microbiological evaluations were performed before cooking (average of $5.03 \mathrm{log}$ $\mathrm{CFU} / \mathrm{g}$ ) after cooking (mean of $1.56 \mathrm{log} \mathrm{CFU} / \mathrm{g}$ ) and after cooling (mean $1.54 \mathrm{log}$ $\mathrm{CFU} / \mathrm{g}$ ) for the caliber $40-44 \mathrm{~mm}$; length $23-26 \mathrm{~cm}$; with weight varying from $260-300$ grams where they were submitted to the cooking and smoking process for at least 5 hours, attending at least $71.1^{\circ} \mathrm{C}$ in the thermal center of the oven. The physicochemical parameters were also evaluated and comply with the legislation, with values

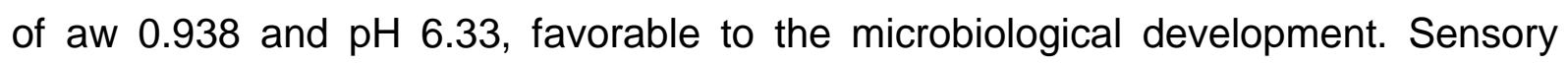
analyzes were also performed to evaluate the sensory attributes along the storage at room temperature.

Keywords: Meat Products. Hurdle Technology. Food Safety. Microbiology. Shelf life. 


\section{LISTA DE FIGURAS}

\section{Capítulo 1}

Figura 1: Fluxograma linguiça cozida

\section{Capítulo 3}

Figura 1: - Carta de controle gerada pela quantificação de Proteínas presentes em linguiças cozidas e defumadas, produzidas entre os meses de maio a outubro de 2018. .67

Figura 2: - Carta de controle gerada pela quantificação de Gordura presente em linguiças cozidas e defumadas, produzidas entre os meses de maio a outubro de 2018. .68

Figura 3: - Carta de controle gerada pela determinação da Umidade em linguiças cozidas e defumadas, produzidas entre os meses de maio a outubro de 2018 69 Figura 4: - Carta de controle gerada pela determinação da Atividade de Água em linguiças cozidas e defumadas, produzidas entre os meses de maio a outubro de 2018. 70

Figura 5: - Carta de controle gerada pela determinação do pH em linguiças cozidas e defumadas, produzidas entre os meses de maio a outubro de 2018 .70

\section{Capítulo 4}

Figura 1 - Gráfico de resultados do shelf-life de linguiças cozidas e defumadas produzidas entre janeiro a outubro de 2018 


\section{LISTA DE TABELAS}

\section{Capítulo 1}

Tabela 1: Padrões físico-químicos de diferentes tipos de linguiça .19

Tabela 2: Padrões microbiológicos de diferentes tipos de linguiça. 20

\section{Capítulo 2}

Tabela 1 - Número de mesófilos (log UFC/g) em gomos de linguiça: antes do cozimento, após cozimento e após resfriamento .56

\section{Capítulo 3}

Tabela 1 - Parâmetros físico-químicos das amostras de linguiças cozidas e defumadas produzidas entre os meses de maio a outubro de 2018

Tabela 2 - Comparação dos dados de pH, umidade e aw da linguiça cozida e defumada produzida pela empresa "A", linguiças fermentadas e salame fabricado no Brasil. .72

\section{Capítulo 4}

Tabela 1 - Atributos avaliados durante o estudo de shelf life das linguiças cozidas defumadas. 79

Tabela 2 - Escala utilizada na avaliação de atributos sensoriais utilizada pela empresa "A", adaptada de Dutcosky, 2015 


\section{LISTA DE SIGLAS}

ABPA - Associação Brasileira de Proteína Animal

APPCC - Análise de Perigos e Pontos Críticos de Controle

ANVISA - Agência Nacional de Vigilância Sanitária

AW - Atividade de Água

$\mathrm{BAL}$ - Bactérias ácido-láticas

BRC - British Retail Consortium

BPF - Boas Práticas de Fabricação

CEP - Controle Estatístico do Processo

CMS - Carne Mecanicamente Separada

FDA - Food and Drug Administration

HPP - High Pressure Preservation (Alta Pressão Hidrostática)

IFS - International Featured Standards

IFST - Institute of Food Science and Technology

GFSI - Global Food Safety Initiative

IN - Instrução Normativa

LAB - Lactic Acid Bacteria (Bactérias Ácido Láctico)

LC - Limite Central

LIC - Limite Inferior de Controle

LSC - Limite Superior de Controle

MAPA - Ministério da Agricultura, Pecuária e Abastecimento

PCC - Ponto Crítico de Controle

PDCA - Plan, Do, Check, Act

PPHO - Procedimentos Padrão de Higienização Operacional

PPR - Programa de Pré-Requisitos

PSO - Procedimentos Sanitários Operacionais

RIISPOA - Regulamento da Inspeção Industrial e Sanitária de Produtos de Origem

Animal

RTIQ - Regulamento Técnico de Identidade e Qualidade

UFC - Unidades Formadoras de Colônias

UR - Umidade Relativa

USDA - United States Department of Agriculture 


\section{SUMÁRIO}

CAPÍTULO 1

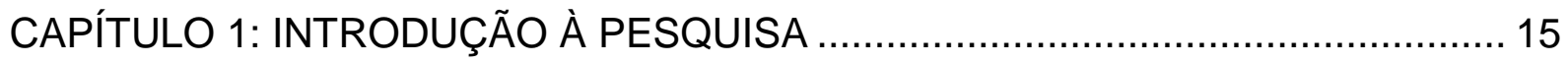

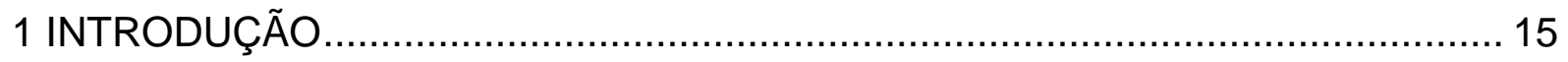

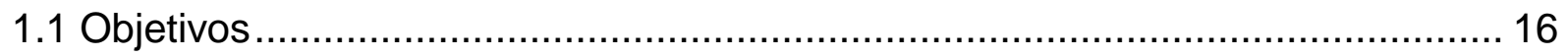

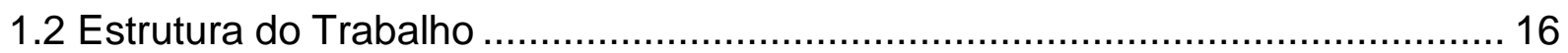

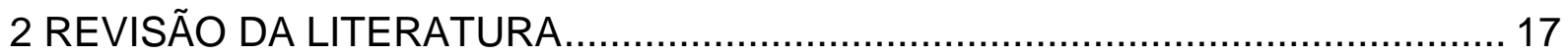

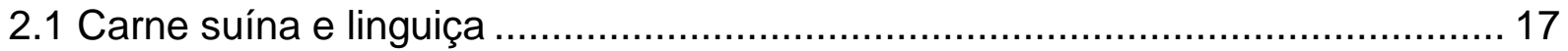

2.2 Parâmetros físico-químicos e microbiológicos para linguiças............................ 19

2.3 Processo de fabricação de linguiças cozidas ................................................ 20

2.4 Ferramentas de gestão na manutenção da qualidade de produtos alimentícios 22

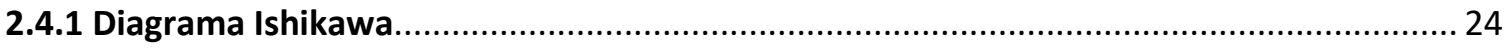

2.4.2 Fluxograma

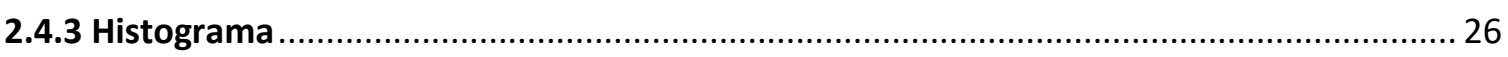

2.4.4 Controle Estatístico do Processo ..................................................................................... 26

2.5 Tecnologia das Barreiras e a segurança de produtos alimentícios.................... 28

2.6 Principais microrganismos deterioradores e patogênicos em linguiças ............... 37

2.6.1 - Bactérias Patogênicas em carnes, aves e derivados........................................................ 37

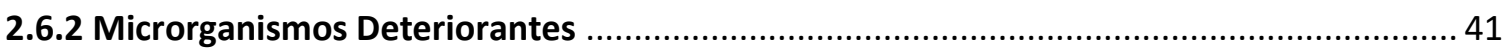

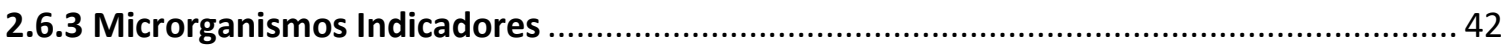

2.7 Descrição da Empresa em estudo ........................................................ 43

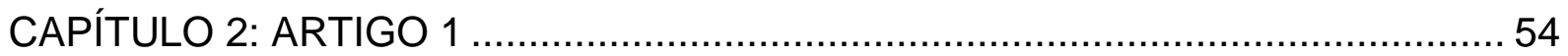

2 AVALIAÇÃO DA QUALIDADE MICROBILÓGICA DAS LINGUIÇAS COZIDAS.... 54

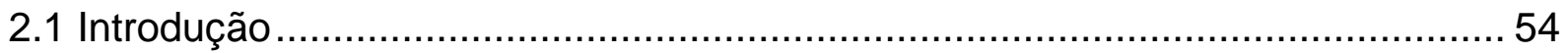

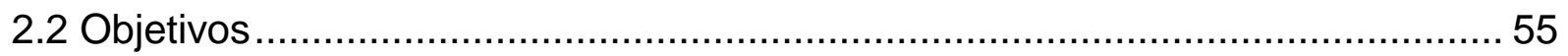

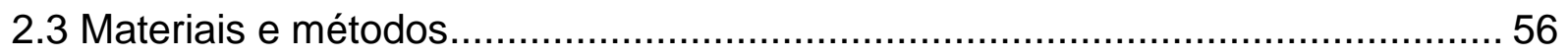

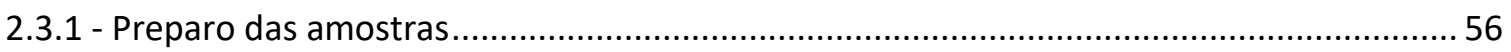

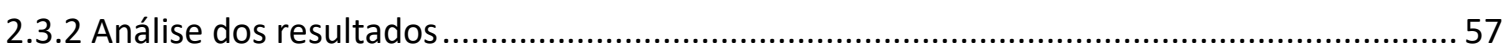

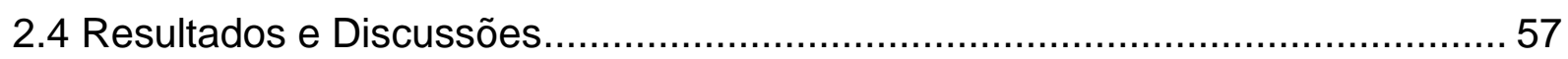

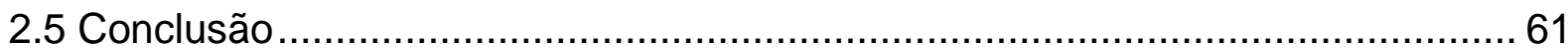


CAPÍTULO 3: ARTIGO 2

3 CARACTERIZAÇÃO FÍSICO-QUÍMICA DAS LINGUIÇAS COZIDAS 65

3.1 Introdução

3.2 Objetivo

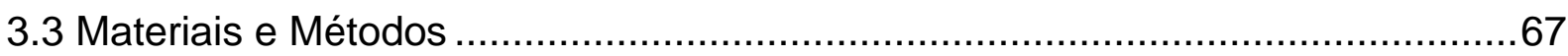

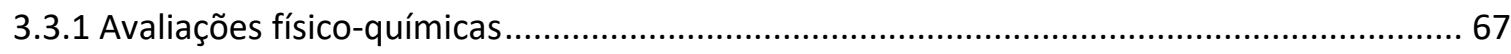

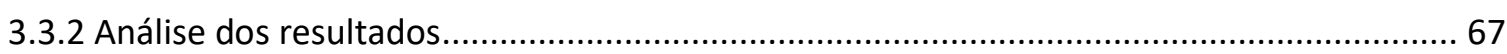

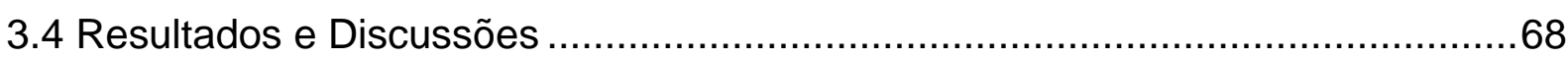

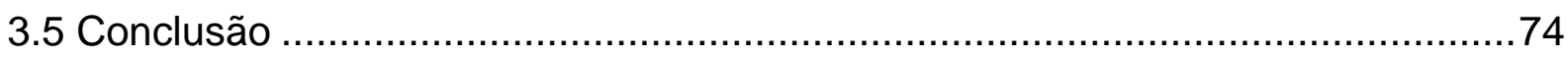

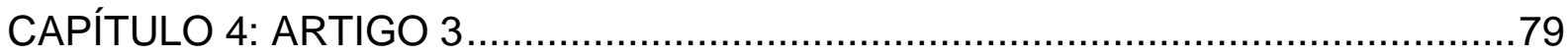

4 ESTUDO DE SHELF-LIFE DAS LINGUIÇAS COZIDAS ................................ 79

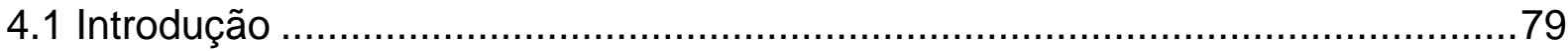

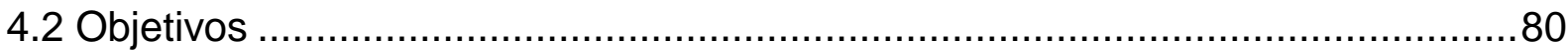

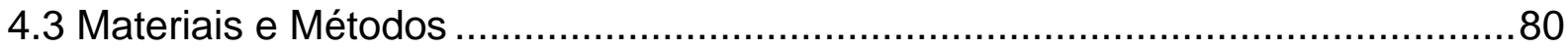

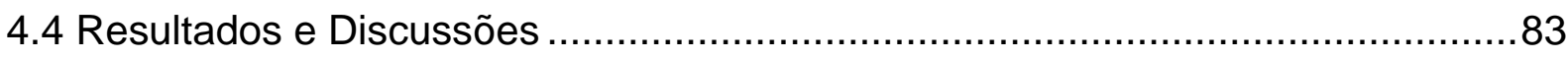

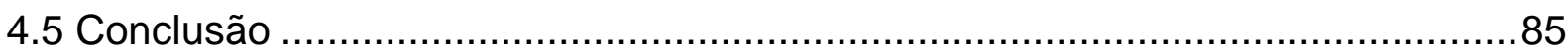

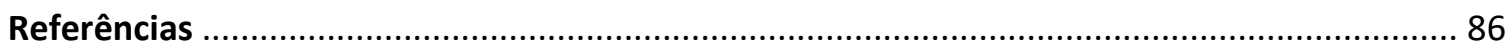

CAPÍTULO 5: CONSIDERAÇÕES E CONCLUSÃO FINAIS ................................ 89

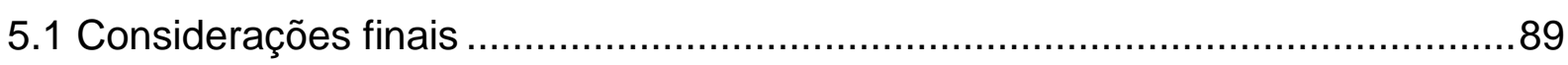

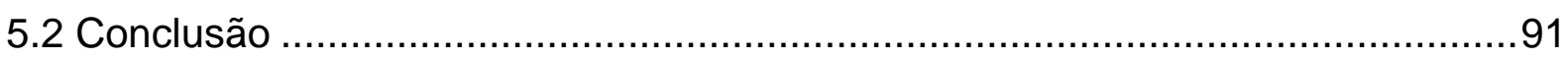

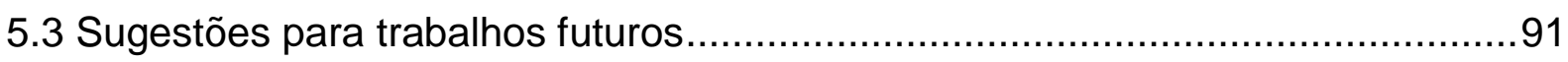

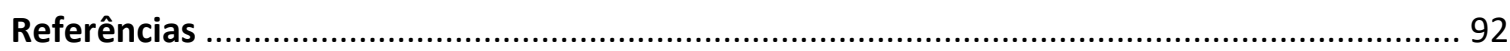




\section{CAPÍTULO 1}




\section{CAPÍTULO 1: INTRODUÇÃO À PESQUISA}

\section{INTRODUÇÃO}

A origem do processamento de carnes é remota e, provavelmente, surgiu a partir do momento que a humanidade aprendeu a trabalhar com o sal como agente de preservação. Os embutidos, particularmente, estão entre as formas mais antigas de processamento de carnes, preservados por um conjunto de métodos, dentre os quais podem ser citadas, a secagem, salga, defumação, condimentação e, às vezes, o cozimento.

Os alimentos cárneos, devido a sua riqueza de umidade, proteínas, gorduras e outros nutrientes, são produtos bastante susceptíveis a alterações de ordem físico-química, microbiológica e sensorial. Entre estas alterações, a oxidação lipídica e a oxidação de pigmentos são difíceis de serem controladas devido à sua complexidade e variabilidade podendo ser potencializada pela ação de microrganismos.

Muitas estratégias são adotadas pelas indústrias processadoras de alimentos para garantir a vida útil do produto, tais como a implantação de programas de qualidade, novas tecnologias, novas embalagens, além de métodos de conservação sejam eles isolados ou combinados. A Teoria das Barreiras, sendo um método de conservação combinado, sugere que os microrganismos em um alimento não devem ser capazes de superar os obstáculos presentes durante o armazenamento de um produto, caso contrário os alimentos podem se deteriorar ou até mesmo poderão causar intoxicação alimentar. A multiplicação ou sobrevivência de microrganismos patógenos ou deteriorantes em alimentos é determinada por fatores intrínsecos ( $\mathrm{pH}$, sal, conservadores, fatores antimicrobianos naturais) e extrínsecos (período e temperatura de armazenamento, atmosfera da embalagem) que podem atuar como barreiras para multiplicação de microrganismo.

Por conseguinte, tendo em consideração que poucos trabalhos forneceram uma abordagem mais sistêmica na indústria de alimentos, indicando ferramentas de gestão da qualidade para a solução de problemas, este estudo propõe uma estrutura com ferramentas e práticas a serem implementadas como busca para a investigação dos problemas de reclamações pelos clientes para linguiças cozidas e 
defumadas, produzidas por uma empresa de grande porte, localizada no interior do Estado de Minas Gerais, doravante denominada de empresa "A".

\subsection{Objetivos}

Identificar quais são as principais causas de deterioração de linguiças cozidas defumadas produzidas pela empresa "A" durante e após seu processamento:

1. Realizar o levantamento microbiológico dos gomos de linguiça em diferentes etapas do processo: antes do cozimento, após cozimento e após resfriamento;

2. Avaliar os resultados de $\mathrm{pH}$, umidade e atividade de água dos meses de maio a outubro de 2018;

3. Avaliar as principais causas de rejeição do produto nos estudos de shelf-life.

\subsection{Estrutura do Trabalho}

Esta dissertação ficou estruturada por cinco capítulos, os quais resumem-se da seguinte forma: o Capítulo 1 apresenta uma introdução a pesquisa, com seus objetivos e fundamentação teórica por uma revisão da literatura e observação do estado da arte no processamento e características de qualidade de linguiças, em especial das linguiças cozidas defumadas, a utilização de ferramentas de gestão na manutenção da qualidade de produtos alimentícios, descrição da teoria das barreiras e sua utilização para a segurança dos alimentos, além de levantamento dos principais microrganismos deterioradores e patogênicos neste tipo de produto. Ainda no capítulo 1 buscou-se apresentar resumidamente a empresa em estudo. No Capítulo 2, estruturado em forma de artigo, buscou-se descrever a caracterização microbiológica das linguiças cozidas defumadas. O Capítulo 3, também em formato de artigo, apresenta a caracterização físico-química das linguiças cozidas defumadas. Já o Capítulo 4, igualmente estruturado como artigo, apresenta o estudo de vida útil do produto ou shelf life, buscando propor soluções de melhoria para o processamento das linguiças cozidas. Finalmente o Capítulo 5 apresenta as considerações finais e sugestões para futuros trabalhos. 


\section{REVISÃO DA LITERATURA}

\subsection{Carne suína e linguiça}

Segundo a revista Suinocultura Industrial $\left(2019_{a}\right.$ ) as exportações de carne suína fecharam em dezembro de 2018 com a marca de 47,8 mil toneladas embarcadas, o que representou um valor de US\$ 94,8 milhões. Com 21 dias úteis a média diária ficou em 2,4 mil toneladas, $8,8 \%$ a mais que a média do mesmo período em 2017. Porém em relação a novembro desse mesmo ano houve uma queda de $6,3 \%$.

O valor pago por tonelada foi maior referente a novembro de 2018, desde que foram pagos US $\$ 1983,90$ por tonelada em dezembro de 2018 ante US $\$ 1855,40$ no mês anterior, representando um crescimento de $6,9 \%$ no valor. Já em relação ao mesmo período de 2017 houve uma desvalorização de $14,5 \%$, visto que o preço pago naquele período era US $\$ 2320,20$ (SUINOCULTURA INDUSTRIAL, 2019a).

A Associação Brasileira de Proteína Animal (ABPA) informa que as exportações de carne suína alcançaram 54,09 mil toneladas em fevereiro de 2019. resultado supera em $26,5 \%$ o volume de carne suína embarcada no mesmo período de 2018, quando foram exportadas 42,7 mil toneladas.

Reaberto em novembro do ano passado, o mercado da Rússia já é o terceiro principal destino do produto brasileiro, ficando atrás de China e Hong Kong (ABPA, 2019). Dados do USDA indicam que as exportações brasileiras de carne suína devem crescer 7\% em 2019 (SUINOCULTURA INDUSTRIAL, 2019b).

A linguiça é uma das mais antigas formas de carne processada de que se tem conhecimento. Não se sabe como e quando a primeira linguiça foi produzida. Existem inúmeros documentos atestando que as civilizações antigas fabricavam e consumiam esses alimentos há alguns milhares de anos atrás.

Os primeiros registros da existência da linguiça datam de 4 mil anos atrás, porém, registros mais exatos remontam a 2 mil anos. Nesta versão da história, a origem da linguiça é romana. Seu nome seria um derivado da palavra "luganega", referente a Lucano. Os Lucanos foram um povo de origem samnita, que se estabeleceu na Lucânia (região montanhosa da Itália meridional) no século $V$ a.C. Muitos séculos atrás essa tribo comandou grande parte daquela península, deixando como legado para os romanos o método de embutir carnes (Dossiê Linguiça..., 2016). 
Atualmente, existem três grupos de linguiça de acordo com o processo de fabricação: fresca - a linguiça in natura, feita de carne crua; cozida - que passa por um pré-cozimento em forno industrial e defumada ou curada - pré-cozida pelo sistema de defumação. A Instrução Normativa № 4/2000 do Ministério da Agricultura do Brasil estabelece o que é oficialmente reconhecido como sendo Mortadela, Linguiça e Salsicha sob a legislação brasileira, especificando nomenclatura e composição de subvariedades específicas (BRASIL, 2000).

De acordo com o Regulamento da Inspeção Industrial e Sanitária de Produtos de Origem Animal (RIISPOA) em seu artigo 288, entende-se por embutidos:

“...Os produtos cárneos elaborados com carne ou órgãos comestíveis curados ou não, condimentados, cozidos ou não, defumados e dessecados ou não, tendo como envoltório tripa, bexiga ou outra membrana animal" (BRASIL, 2017).

Também de acordo com o Regulamento da Inspeção Industrial e Sanitária de Produtos de Origem Animal (RIISPOA), entende-se por linguiça:

"...O produto cárneo industrializado, obtido de carnes de animais de açougue, adicionados ou não de tecidos adiposos, ingredientes, embutido em envoltório natural ou artificial, e submetido ao processo tecnológico adequado. A linguiça calabresa é o produto obtido exclusivamente de carnes suína, curado, adicionado de ingredientes, devendo ter o sabor picante característico da pimenta calabresa submetidas ou não ao processo de estufagem ou similar para desidratação e ou cozimento, sendo o processo de defumação opcional. Nas linguiças denominadas Tipo Calabresa, Tipo Portuguesa e Paio, que são submetidas ao processo de cozimento, será permitido a utilização de até $20 \%$ de CMS - Carne Mecanicamente Separada, desde que seja declarado no rótulo de forma clara ao consumidor a expressão ।"carne mecanicamente separada de ....।" (espécie animal), além da obrigatoriedade de constar na relação de ingredientes a expressão \"contém...।" ou \"com CMS (espécie animal)।". A 
CMS utilizada poderá ser substituída pôr carne de diferentes espécies de animais de açougue, até o limite máximo de 20 $\% "$ (BRASIL, 2000).

\subsection{Parâmetros físico-químicos e microbiológicos para linguiças}

As características físico-químicas das linguiças além de fornecer informações nutricionais também são utilizadas como um dos parâmetros para avaliar a qualidade do produto. Na Tabela 1 estão descritos os requisitos em relação às características físico-químicas, estipuladas pelo Regulamento Técnico de Identidade e Qualidade de Linguiça (BRASIL, 2000).

Tabela 1: Padrões físico-químicos de diferentes tipos de linguiça

\begin{tabular}{|c|c|c|c|}
\hline & $\begin{array}{l}\text { LINGUIÇAS } \\
\text { FRESCAIS }\end{array}$ & $\begin{array}{l}\text { LINGUIÇAS } \\
\text { COZIDAS }\end{array}$ & $\begin{array}{l}\text { LINGUIÇAS } \\
\text { DESSECADAS }\end{array}$ \\
\hline Umidade & (máx.) - 70\% & (máx.) - 60\% & (máx.) - 55\% \\
\hline Gordura & (máx.) $-30 \%$ & (máx.) - 35\% & (máx.) $-30 \%$ \\
\hline Proteína & (mín.) - 12\% & (mín.) - 14\% & (mín.) - 15\% \\
\hline Cálcio (b.s*) & (máx.) - 0,1\% & (máx.) - 0,3\% & (máx.) - 0,1\% \\
\hline
\end{tabular}

*b.s = base seca

FONTE: BRASIL (2000).

Visando proteção da saúde dos consumidores, a Agência Nacional de Vigilância Sanitária (ANVISA), por meio do Regulamento Técnico sobre padrões Microbiológicos para Alimentos, estabelece padrões microbiológicos sanitários limites para a presença de alguns grupos ou espécies de microrganismos, nas diferentes categorias de alimentos destinados ao consumo humano (BRASIL, 2001). Na Tabela 2 estão relacionados os padrões microbiológicos que as linguiças, de diferentes tipos, devem atender, para que o produto seja próprio para o consumo humano. Os cuidados em toda a cadeia produtiva, desde a produção da matéria-prima, no processamento, nos equipamentos e utensílios higienizados, a temperatura adequada, bem como as condições higiênico-sanitárias dos manipuladores e o armazenamento do produto acabado, influenciará no controle dos microrganismos deteriorantes e patogênicos. 
Tabela 2: Padrões microbiológicos de diferentes tipos de linguiça

\begin{tabular}{|c|c|c|c|c|c|c|}
\hline \multirow{2}{*}{$\begin{array}{l}\text { Grupo de } \\
\text { Alimentos }\end{array}$} & \multirow{2}{*}{ Microrganismo } & \multirow{2}{*}{$\begin{array}{l}\text { Tolerância } \\
\text { para } \\
\text { amostra } \\
\text { indicativa }\end{array}$} & \multicolumn{2}{|c|}{$\begin{array}{l}\text { Tolerância } \\
\text { representativa }\end{array}$} & para & amostra \\
\hline & & & $\mathrm{n}$ & c & $\mathrm{m}$ & M \\
\hline \multirow{3}{*}{ Linguiças } & Coliformes a $45^{\circ} \mathrm{C} / \mathrm{g}$ & $10^{3}$ & 5 & 2 & $10^{2}$ & $10^{3}$ \\
\hline & $\begin{array}{l}\text { Estafilococos } \\
\text { coagulase positiva/g }\end{array}$ & $5 \times 10^{3}$ & 5 & 1 & $10^{3}$ & $5 \times 10^{3}$ \\
\hline & Salmonella sp/25g & Ausente & 5 & 0 & Ausente & - \\
\hline
\end{tabular}

FONTE: BRASIL (2001)

\subsection{Processo de fabricação de linguiças cozidas}

Como o estudo foi realizado em uma empresa de grande porte, denominada de empresa "A", localizada no interior do Estado de Minas Gerais, que produz entre outros produtos a linguiça cozida e defumada, representando um dos carros chefes da empresa, será descrito a seguir o processamento deste produto, porém maior detalhamento encontra-se no item 2.7. O processo de fabricação da linguiça cozida na empresa segue de forma resumida conforme o fluxograma apresentado na Figura 1.

As matérias-primas utilizadas no processo produtivo, são oriundas de carcaças provenientes dos abatedouros da própria empresa. São recebidas resfriadas $\leq 5^{\circ} \mathrm{C}$ e/ou congeladas $-18^{\circ} \mathrm{C}$ para CMS (Carne Mecanicamente Separada) e $-12^{\circ} \mathrm{C}$ ou mais frio para as demais.

Parte dos ingredientes descritos na formulação são processados em cutter e/ou emulsificador para formar uma "pré-mistura" (emulsão), que é agregada posteriormente à massa. As matérias-primas moídas, emulsão e os demais ingredientes são misturados em misturadeira por 2 a 4 minutos, aproximadamente.

A tripa natural utilizada neste processo é hidratada com uma solução de água e fosfatos no período que antecede o embutimento. Após esta etapa, a massa é embutida e torcida para formar os gomos e as pontas são fechadas com lacre plástico. As dimensões do gomo são: calibre de $40-44 \mathrm{~mm}$; comprimento $23-26 \mathrm{~cm}$; com peso variando de 260-300 gramas. 
Figura 2: Fluxograma linguiça cozida

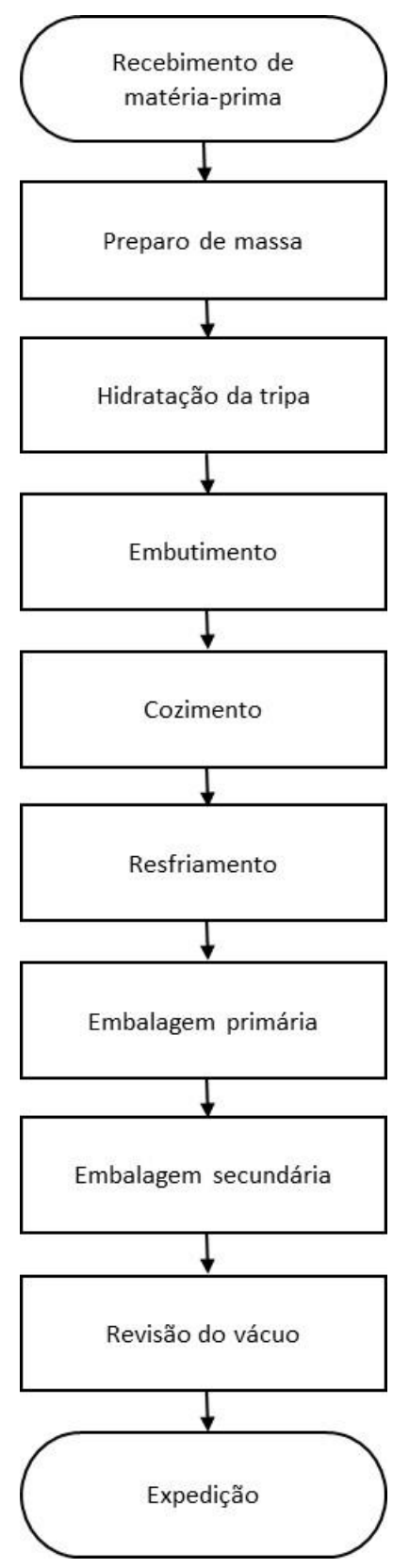

Fonte: Própria autoria

Em seguida, as linguiças são levadas para o cozimento e defumação com fumaça natural, em estufas construídas para esta finalidade, a partir da queima da serragem, por no mínimo 5 horas, atendendo no mínimo $71,1^{\circ} \mathrm{C}$ no centro térmico do gomo. É nesse processo que ocorre a obtenção das características de produto defumado tais como cor, odor e sabor e a redução da umidade e atividade de água do produto. O resfriamento acontece com utilização de ar frio, de maneira a garantir que a temperatura do produto não seja superior a $20^{\circ} \mathrm{C}$. 
Então o produto é embalado em saco plástico impresso à vácuo, selado e segue para o setor de embalagem secundária onde é acondicionado em caixas de papelão impressas, identificadas com etiqueta adesiva, seladas com fita adesiva, paletizadas e envolvidas por filme stretch.

\subsection{Ferramentas de gestão na manutenção da qualidade de produtos alimentícios}

Ferramentas da qualidade são essenciais e indispensáveis para a melhoria de projetos para obter o máximo de eficiência e eficácia. Além disso, essas ferramentas foram desenvolvidas e aprimoradas para apoiar a implementação bemsucedida da gestão da qualidade nas empresas (OLIVEIRA, 2011). Baker et al. (2014) sugerem que o uso de técnicas e ferramentas de qualidade é essencial para determinar as causas de um problema e para identificar ações a serem tomadas para eliminá-lo. Em outras palavras, sua aplicabilidade é focada principalmente na análise de processos e estruturação do plano de ação.

Os processos de melhoria contínua e resolução de problemas são baseados no ciclo PDCA, que são as iniciais das palavras em inglês Plan, Do, Check e Act, e assim conhecida aqui no Brasil. Vários estudos demonstram que essa ferramenta proporciona significativos benefícios às empresas, por ser uma ferramenta de planejamento. Dentre os benefícios, os que mais se destacam são a melhoria nos processos, produtos e serviços, aumento da satisfação dos clientes, melhoria da imagem da empresa, abertura de novos mercados e maior vantagem competitiva diante da concorrência.

Atualmente, o ciclo PDCA é caracterizado por sua abordagem de melhoria contínua e é reconhecido como um programa lógico que permite melhorar as atividades. As linhas a seguir descrevem os quatro estágios do ciclo PDCA (CAMPOS, 2004):

- "Plan" (P) está associado ao reconhecimento da possibilidade de mudanças, ou seja, sua melhoria e programação. Estabelece os objetivos de melhoria e elabora um plano de ação que possibilitará esse objetivo. É necessário identificar o problema, analisar as causas que o afetam, gerar soluções e desenvolver um plano de implementação. 
- "Do" (D) o plano desenvolvido para fazer mudanças no processo é implementado em uma empresa (a fim de aumentar sua produtividade ou qualidade e eliminar as causas dos problemas). Acontece com o apoio e compreensão da gestão.

- "Check" (C) é igual à verificação, teste, se as soluções apresentadas a uma empresa trouxeram resultados adequados. As medições são feitas e comparadas com os valores desdobrados no plano.

- "Act" (A) está conectada com a aplicação das soluções implementadas. Quando essas soluções são comprovadas, elas são consideradas normativas e levam à padronização e monitoramento das atividades.

A literatura mostra que diferentes aplicações do Ciclo PDCA foram implementadas, como por exemplo: (1) Prashar (2017) utilizou-a para a melhoria contínua da eficiência energética de uma fábrica de papel indiana; (2) Dudin (2017) utilizou-a para resolução de problemas de deficiência e baixa disponibilidade de alimentos de boa qualidade nos países em desenvolvimento, melhorando a qualidade dos produtos agrícolas, otimizando a estrutura dos processos de negócios e organização dos serviços; (3) Jagusiak-Kocik (2017) reduziu em mais $60 \%$ o número de não conformidades relacionadas à qualidade de molduras fotográficas (descoloração e queimaduras na superfície do quadro), após a implementação do ciclo PDCA; (4) Realyvásquez-Vargas (2018) aumentou a qualidade e a capacidade das linhas de produção, após reduzir os defeitos que eram gerados da soldagem em placas eletrônicas e seus componentes, numa empresa de manufatura; (5) Silva (2017) reduziu o índice de perdas de latas de um fabricante multinacional de bebidas, com melhorias de qualidade e produtividade na organização, como resultado da implementação do Ciclo PDCA.

Diante desses trabalhos, evidenciamos que o Ciclo PDCA é uma ferramenta simples e pode ser usado com sucesso em qualquer empresa que utilize ou pretenda aplicar o princípio da resolução de problemas e ou melhoria em relação a algumas ou todas as áreas de seus negócios.

Para executar as etapas do Ciclo PDCA de maneira eficaz, outras ferramentas de qualidade podem ser necessárias, que podem ser utilizadas com a 
finalidade de definir, mensurar, analisar e propor soluções para problemas utilizando dados quantitativos e são divididas em sete: Fluxograma, Diagrama Ishikawa (Espinha-de-Peixe), Folha de Verificação, Diagrama de Pareto, Histograma, Diagrama de Dispersão e Cartas de Controle. Neste projeto foram usados o Diagrama Ishikawa, Fluxograma e ferramentas gráficas do Histograma e Cartas de Controle.

\subsubsection{Diagrama Ishikawa}

O diagrama de Ishikawa, também conhecido como diagrama de causaefeito, mostra as causas de um problema de qualidade específico em sua dependência mútua (DZIUBA et al., 2014; SUÁREZ-BARRAZA et al.,2018), que consiste na investigação das principais causas e suas sub-causas (CHOKKALINGAM et al. 2017).

O Diagrama de Ishikawa tem um objetivo principal, que é usar o brainstorming para identificar causas maiores e menores por trás de um efeito, então desdobrar em um plano de ação para tratar as causas (METHA, 2014).

As versões focam principalmente nas definições que incluem o Acrônimo "6M", para sua contrução: maquinário (tecnologia), mão de obra (trabalho físico), material (matéria prima), medição (inspeção), meio ambiente (Local) e método (processo). Alguns autores incluem a categoria "Gestão" (LI; LEE, 2011) e Metha (2014) acrescenta à categoria "Informações". Para cada categoria, começamos a construir as relações de causa e efeito geradas em um processo dedutivo a partir do mais geral para o mais específico e particular, até chegarmos a um quarto ou quinto nível de profundidade das relações de causa e efeito centradas em cada categoria (SUÁREZ-BARRAZA et al.,2018).

Normalmente, nas configurações de fabricação, a aparência da não conformidade é analisada devido a causas principais, como: homem, máquina, material, método, gerenciamento e ambiente. Em configurações de serviço, Máquina e Método são frequentemente substituídos por Políticas (regras de decisão de alto nível) e Procedimentos (tarefas específicas). Número das causas depende da complexidade do problema, pode ser diferente e não precisa ser estritamente limitado a 6M (DZIUBA et al., 2014).

Rábago-Remy et al. (2014), realizaram uma análise de capacidade do processo de envase de massa de tomate e verificaram que era instável, altamente 
variável e não atendia às especificações. Em consequência disso, realizaram uma análise para identificar as causas potenciais do excesso de enchimento das latas. As causas potenciais que poderiam ter um efeito sobre o peso líquido das latas de massa de tomate foram gerados por brainstorming e, em seguida, foram organizados em um diagrama de causa e efeito.

Chokkalingam et al. (2017) utilizaram o diagrama de Ishikawa para identificar a causa raiz dos defeitos de encolhimento em um corpo de carcaça de automóvel, no processo de produção de semi-eixos de transmissão, e verificaram que as causas principais eram maior volume na seção, alimentação insuficiente de riser e metal vazado, as medidas corretivas necessárias foram tomadas e as carcaças foram reproduzidas e o defeito de encolhimento nas carcaças foi completamente eliminado.

Li \& Lee (2011), utilizaram o Diagrama de Ishikawa para representar a relação dos fatores identificados para o sucesso do investimento em TI. Segundo os autores, embora este diagrama tem sido amplamente utilizado na área de gestão, o diagrama também é útil no planejamento e execução do diagrama na área de ciência e tecnologia.

\subsubsection{Fluxograma}

Um fluxograma é uma ferramenta visual que mostra o fluxo de trabalho para um processo de trabalho específico, facilitando a compreensão, padronização e melhoria de tal processo. Mais precisamente, um fluxograma é uma imagem que contém as etapas de um processo de trabalho. Utiliza símbolos diferentes para representar diferentes tipos de atividades de um processo. Por exemplo, ele usa caixas ou retângulos para representar as atividades ou etapas do processo ou tarefa, ovais ou círculos para indicar o início e o fim do processo, diamantes para indicar que a decisão deve ser feita, bem como setas para indicar a sequência de passos (PRÍSTAVKA et al., 2016; CAMPOS, 2004).

Para Campos (2004), utiliza-se o fluxograma com dois objetivos: garantir a qualidade e aumentar a produtividade, essa ferramenta é o início da padronização. O Fluxograma tem como finalidade identificar o caminho real e ideal para um produto ou serviço com o objetivo de identificar os desvios. É uma representação sequencial de todas as etapas de um processo, de modo a se obter uma visão integrada do fluxo, utilizando símbolos gráficos padronizados. 
Prístavka et al. (2016), implementou o fluxograma em uma organização, a fim de descrever processos em documentação controlada. Além dos objetivos de qualidade, a documentação controlada é escrita para cada divisão separadamente. Um texto é por vezes muito difícil de compreender, e seria mais fácil de entender se o fluxograma fosse adicionado a cada documento controlado pouco antes da descrição do processo. O processo é apresentado de maneira mais abrangente por fluxograma, em vez de várias páginas de texto.

\subsubsection{Histograma}

O histograma auxilia na observação de dados (PRíSTAVKA et al., 2016) ou ainda, na avaliação da dispersão (CAMPOS, 2004). Todas as características de um produto ou serviço apresentam naturalmente uma variabilidade, porém, se o processo estiver sob controle estatístico, essa variabilidade se dará de acordo com um padrão que é conhecido com distribuição (CAMPOS, 2004).

Para Dudin (2017), um dos benefícios dessa ferramenta é a visibilidade e simplicidade de adoção e uso, porém o histograma pode levar a conclusões erradas, quando se utiliza uma amostragem pequena.

Prístavka et al. (2016), utilizou o histograma para dar visibilidade aos resultados das não conformidades internas no processo e para melhorar a identificação das principais causas das não conformidades na área de produção de chapas metálicas de uma empresa.

\subsubsection{Controle Estatístico do Processo}

A demanda dos consumidores, devido às exigências por qualidade, implica grandes esforços ao nível de garantir a estabilidade dos processos e de minimizar a variabilidade em torno dos valores desejados para as características de qualidade.

A variabilidade é inerente a todo processo devido a duas causas principais: (a) causas naturais ou comuns, e (b) causas especiais ou atribuíveis. Um processo que opera apenas com causas comuns de variação está em estado de controle estatístico (MAHESH; PRABHUSWAMY, 2010). O Controle Estatístico do Processo (CEP) é uma ferramenta de qualidade usada para detectar a ocorrência de causas atribuíveis e onde possível, eliminar a variabilidade nos processos (GILDEH, 2014). 
Cartas (ou gráficos) de controle são utilizadas para monitorar o desempenho de um processo de medição. Estes gráficos determinam estatisticamente uma faixa denominada limites de controle, que é limitada por uma linha superior (limite superior de controle - LSC) e uma linha inferior (limite inferior de controle - LIC), além de uma linha central (limite central - LC) (CAMPOS, 2004).

O CEP é amplamente aceito para analisar problemas de qualidade, melhorar o desempenho do processo e eliminar a variabilidade nos processos de produção (MAHESH; PRABHUSWAMY, 2010; GILEH et al., 2014; ABREU et al., 2018).

Para Kharbach et al.(2017), o CEP é definido como a capacidade de um processo produzir saída dentro dos limites de especificação, é frequentemente realizado para verificar o desempenho do processo de fabricação.

Segundo Pereira e Requeijo (2012), principal objetivo do CEP é monitorar processos sequenciais, para garantir que eles operem de forma estável e satisfatória, construindo um gráfico de controle estatístico que permita não apenas reduzir a variabilidade inerente do processo, mas também estimar os parâmetros e determinar se é capaz de produzir de acordo com as especificações definidas na fase de projeto e desenvolvimento. Além disso, as ações corretivas podem ser tomadas antes que muitas unidades não-conformes sejam fabricadas (MAHESH; PRABHUSWAMY, 2010).

O CEP tornou-se uma ferramenta crucial para garantir a vantagem competitiva de qualquer empresa em relação à concorrência (ABREU et al., 2018). Embora não seja um requisito obrigatório na indústria alimentícia, ele pode fornecer benefícios para as organizações do setor, independentemente de sua especialidade e tamanho (DJEKIC et al., 2014)

O CEP é visto como uma técnica poderosa sob a gestão da qualidade dos alimentos através de atividades de controle e melhoria de qualidade. No entanto, a literatura sugere que sua implementação na indústria de alimentos ainda é baixa em comparação com outras ferramentas de controle de qualidade (LIM et al., 2015; LIM et al., 2016).

Djekic et al. (2015) utilizou controle estatístico de processo na análise dos parâmetros de qualidade do queijo, sendo dois tipos: queijos brancos salgados e queijo de leite ultrafiltrado. Verificou que o único parâmetro estável em ambos os tipos de queijo foi a umidade nos sólidos sem gordura. Todos os parâmetos das demais 
características de qualidade do queijo foram caracterizadas acima ou abaixo dos limites de controle para a maioria das amostras. Tais resultados indicaram uma alta instabilidade e variações na produção de queijo.

O estudo de Rábago-Remy et al. (2014) avaliou, pelas cartas de controle, que o processo de envase de latas de massa de tomate não estavam sob controle, com elevada variação e não atendendo às especificações, durante os meses avaliados, gerando problemas de excesso enchimento das latas, o que se refletia na qualidade do produto acabado e em perdas econômicas.

Abreu et al. (2018) realizou a implementação do Controle Estatístico do Processo na indústria vitivinícola para melhorar a qualidade do produto final uma vez que é necessário ter alguns cuidados como por exemplo o evitar a ocorrência de contaminações microbiológicas ou a oxidação do vinho.

A literatura existente apoiou a aplicabilidade e vantagens da implementação do CEP na indústria alimentícia não apenas no processamento, mas também na embalagem. Por exemplo, Djekic et al., (2014), implementaram CEP para o controle de processo no setor de embalagens de sete empresas de alimentos do setor de laticínios. Até o momento, nenhuma delas tinha algum tipo de controle de processo estatístico em vigor. Os resultados confirmaram que a maioria das empresas apresentavam embalagens com excesso de peso.

Outros benefícios percebidos da aplicação na indústria de alimentos incluem a melhoria da segurança do produto, por exemplo, para análise de tendências, monitoramento e avaliação do controle dos pontos críticos estatisticamente, obtendo aviso prévio sobre o status de um ponto de controle crítico (PCC) e não apenas uma classificação "Pass / Fail", ou seja, "Aprovado / Reprovado", e medição de saídas do processo e identificando se eles variam dentro dos limites de controle superior e inferior estatisticamente definidos (DALGIÇ, 2011).

\subsection{Tecnologia das Barreiras e a segurança de produtos alimentícios}

Os consumidores estão cada vez mais exigentes quanto a elevada qualidade dos alimentos, e têm a expectativa de que tal qualidade será também mantida em nível elevado durante o período entre a compra, armazenamento e consumo. Essas expectativas são uma consequência não apenas da exigência de que o alimento deve permanecer seguro, mas também da necessidade de minimizar as alterações indesejadas em suas qualidades sensoriais. 
As diretrizes do IFST (Institute of Food Science and Technology), de 1993, fornecem uma definição para vida útil de um alimento ou shelf life (conforme seu termo em inglês): tempo durante o qual o produto alimentício irá permanecer seguro, mantendo as características sensoriais, físico-químicas e microbiológicas desejadas e cumprir com qualquer declaração constante no rótulo quanto aos seus dados nutricionais, quando armazenado nas condições recomendadas.

Existem fatores intrínsecos e extrínsecos que podem influenciar vida útil de um alimento. Os fatores intrínsecos são as propriedades do produto final, e incluem atividade da água (aw), valor de $\mathrm{pH}$, acidez, potencial de oxido-redução (Eh), oxigênio disponível, nutrientes, microflora natural e contagem de microrganismos sobreviventes; bioquímica natural da formulação do produto (enzimas, reagentes químicos) e uso de conservantes na formulação do produto (IFST, 1993; MASSAGUER, 2005). Esses fatores são influenciados por variáveis, como o tipo de matéria-prima e qualidade, e pela formulação do produto e estrutura.

Os fatores extrínsecos são os que o produto final encontra à medida que ele se move através da cadeia produtiva, incluindo perfil de tempo-temperatura durante o processamento, variabilidade espacial de pressão; controle de temperatura durante 0 armazenamento e distribuição; umidade relativa (UR) durante o processamento, armazenamento e distribuição; exposição à luz ultravioleta (UV) e infravermelho (IV) durante o processamento, armazenamento e distribuição; contagem microbiana ambiental durante o processamento, armazenamento $\mathrm{e}$ distribuição; composição da atmosfera dentro das embalagens.

Muitas estratégias são adotadas pelas indústrias processadoras de alimentos para garantir a vida útil do produto, como a implantação de programas de qualidade, novas tecnologias, novas embalagens, além de métodos de conservação sejam eles isolados ou combinados.

Os produtos cárneos, devido a sua riqueza em umidade, proteínas, gorduras e outros nutrientes, são produtos bastante susceptíveis a alterações de ordem físico-química, microbiológica e sensoriais, dentre essas alterações podemos citar a redução do $\mathrm{pH}$, aumento da contagem microbiológica e alterações de cor, sabor e odor.

Assim, as indústrias de alimentos devem ter os meios disponíveis para prever a vida útil do alimento, sob determinado conjunto de condições de armazenamento. Os critérios com base na contagem de microrganismos deteriorantes 
e patogênicos e seu padrão de crescimento são capazes de auxiliar nessa definição. Pode-se também definir as características sensoriais desejadas utilizando-se de testes de avaliação sensorial com consumidor e avaliar a variação por meio de escalas de aceitação.

Na busca por alimentos saudáveis, estáveis com suas características sensoriais preservadas, a indústria de alimentos pode usar uma combinação de métodos de preservação, denominados Tecnologia das Barreiras ou Tecnologia dos Obstáculos de Leistner, que segundo McMeekin et al., (2002) é o conjunto de condições necessárias e fatores de conservação combinados, para prevenir o crescimento de microrganismos, ou mesmo causar sua inativação na busca por alimentos saudáveis, que permaneçam estáveis e inócuos, mantendo suas características organolépticas e nutricionais aceitáveis.

Singh (2016) define Tecnologia das Barreiras como uma tecnologia pela qual um parâmetro de preservação pode ser usado em um nível ótimo para obter um letalidade máxima contra microrganismos por uma combinação de dois ou mais desses parâmetros, de modo que o dano aos atributos sensoriais do alimento são mínimos, ou ainda uma preservação inteligente, usando diferentes técnicas (barreiras) para controlar ou eliminar patógenos.A Tecnologia das Barreiras é aplicada para a preservação suave, mas eficaz de alimentos. Anteriormente, uma combinação de métodos de preservação, era usada empiricamente sem conhecimento dos princípios dominantes. Há cerca de 20 anos, a aplicação inteligente da tecnologia de obstáculos tornou-se mais prevalente, porque os princípios dos principais fatores de preservação para alimentos (por exemplo, temperatura, pH, aw, Eh, flora competitiva), e suas interações, tornaram-se mais conhecidas. Recentemente, a influência dos métodos de conservação de alimentos na fisiologia e o comportamento de microrganismos nos alimentos, isto é, sua homeostase, exaustão metabólica, reações de estresse, são levados em conta e assim, surgiu o novo conceito de preservação de alimentos múltipos alvos (LEISTNER, 2000).

O número de barreiras já aplicadas e potenciais barreiras para a preservação de alimentos chega a mais de 100 e, portanto, as indústrias de alimentos têm inúmeras opções.

Atualmente, tecnologias pulsadas e Conservantes "naturais" atraem muito interesse entretanto, eles são mais eficazes em combinação com a preservação de métodos tradicionais (isto é, barreiras). Eles incluem entre outros, controle de $\mathrm{pH}$, 
redução da atividade de água, pasteurização, calor moderado cujos objetivos podem incluir a destruição de enzimas e redução da carga microbiana, incorporação de antimicrobianos naturais, manuseio e enchimento do tipo ultra clean/asséptico, rápida redução da temperatura do produto, manutenção da temperatura durante toda a distribuição, redução de oxigênio dentro e ao redor do produto, elevação do óxido de carbono dentro e em volta do produto, embalagem de barreira de gás para manter a taxa de deterioração e embalagem ativa e como removedor de oxigênio da embalagem (SINGH, 2016).

O processamento térmico é ainda um dos métodos mais eficazes para a inativação de microrganismos indesejáveis nos alimentos. O calor é usado para inativar patógenos e desenvolver sabores, aromas, textura e cor típicos de um alimento cozido. A pasteurização produz alimentos mais seguros com maior prazo de validade. Como temperaturas amenas são aplicadas por um tempo determinado, técnicas complementares de conservação de alimentos, como atmosferas modificadas, adição de conservantes ou o uso de armazenamento e distribuição refrigerados, podem ser necessárias para controlar o crescimento dos microrganismos sobreviventes (SILVA, 2012).

A inativação térmica evita 0 processamento excessivo dos produtos alimentícios, inativando os microrganismos através da perturbação a membrana celular, ácidos nucleicos e ribossomos, no entanto, os mecanismos destas modificações macromoleculares permanecem desconhecidos. O processamento térmico poderia ser considerado a técnica ideal para a preservação de alimentos. No entanto, devido à termotolerância de certas enzimas nos alimentos torna-se necessário aplicar tratamentos térmicos mais intensos, que alteram as propriedades organolépticas e nutricionais dos alimentos (Raso \& Barbosa-Canovas, 2003).

Os produtos de carne devem conter obstáculos suficientes para inibir o crescimento de microrganismos patogênicos ou deteriorantes. Há inúmeros pontos nas etapas de produção das linguiças cozidas defumadas, onde a combinação de fatores intrínsecos e extrínsecos podem influenciar na vida útil do alimento, incluindo seleção e qualidade das matérias-primas, formulação do produto (atividade de água, pH e presença de conservantes), ambiente de processamento, cozimento e embalagem.

Mataragas et al. (2015) desenvolveram um modelo preditivo para avaliar os efeitos relativos do $\mathrm{pH}$, atividade de água (aw) e temperatura em L. monocytogenes durante a fermentação e maturação de linguiças. Observaram que a temperatura 
explicava $60 \%$ da variabilidade dos dados, enquanto $\mathrm{pH}$ e aw, apenas uma pequena parte, porém, a temperatura sozinha pode não ser suficiente para causar a inativação do patógeno, mas a taxa de inativação é dominada pela temperatura quando o $\mathrm{pH} \mathrm{e}$ o aw estão na faixa que impede o crescimento de $L$. monocytogenes.

Hoje em dia, a preservação de quase todos os alimentos é baseada em uma aplicação combinada de vários métodos de preservação para atingir o máximo de eficácia microbiana pelos efeitos sinérgicos em células microbianas (SINGH, 2016). Os conceitos da tecnologia das barreiras foram adotados por vários pesquisadores para o processamento de produtos alimentícios. Abaixo estão listados uma diversidade de combinações de potenciais obstáculos para carnes e produtos cárneos, de pesquisas realizadas recentemente. No entanto, há uma grande dificuldade de se encontrar trabalhos para linguiças cozidas defumadas para barreiras adicionais às já aplicadas atualmente.

Ácidos orgânicos fracos são amplamente utilizados como conservantes e desinfetantes na indústria alimentícia. Apesar de seu uso difundido, o modo antimicrobiano de ação dos ácidos orgânicos ainda não é totalmente compreendido (TAN et al.,2015).

Ácidos orgânicos têm sido utilizados há muitos anos para descontaminação de produtos de carne bovina, suína e aves de várias bactérias, incluindo Salmonella. Atualmente relatórios descrevem novos tratamentos com ácidos orgânicos usando a abordagem de tecnologia de obstáculo para inibir Salmonella. Além disso, ações preventivas devem ser tomadas para diminuir a aparência de cepas resistentes de Salmonella como resultado de tratamentos insuficientes ou sub-letais com ácidos orgânicos em produtos de carne e aves (MANI-LOPEZ, 2012).

Omoria et al. (2017) avaliaram o efeito do ácido lático na resistência ao calor de Listeria monocytogenes e demonstraram o controle efetivo desta bactéria quando utilizado a combinação de um ácido orgânico e temperatura.

Tratamentos combinados usando vapor e ácido láctico (pulverização com solução a 2\%) também foram realizados por Pipek et al. (2006) e observaram a extensão da vida útil de carcaças suínas. Esta combinação diminuiu acentuadamente a contagem de patógenos e deteriorantes e retardou o crescimento microbiano durante o armazenamento.

Carpenter et al. (2011) realizaram a comparação de lavagem com spray a $55,4^{\circ} \mathrm{C}$ e concentração de $2 \%$ de ácido levulínico, ácido lático ou ácido acético para 
descontaminação de bactérias patogênicas inoculadas em superfícies de carne, e sua proteção residual contra crescimento posterior de bactérias patogênicas. Os ensaios incluíram Escherichia coli O157: H7 na placa de carne bovina, Salmonella na pele de frango e barriga de porco e Listeria monocytogenes no peru. Nos estudos de descontaminação, lavagens com ácidos reduziram o número de patógenos em comparação com os controles (sem lavagem) porém, apenas ácido lático reduziu o número de patógenos em comparação com a lavagem somente com água. Este resultado reforça a eficácia da adição de ácidos orgânicos, pela capacidade combinada, de descontaminar os tecidos da carne e subsequentemente inibir os patógenos, especialmente a medida em que lavar com ácidos orgânicos contribui para um programa total de segurança dos alimentos.

Gonzalez-Fandos \& Herrera (2014) avaliaram o efeito do ácido acético sobre o crescimento de $L$. monocytogenes em coxas de frango armazenadas a $4^{\circ} \mathrm{C}$ por oito dias e concluiram que a aplicação deste ácido orgânico pode ser usada como um obstáculo adicional, contribuindo para estender a vida de prateleira de aves cruas e reduzir as populações de $L$. monocytogenes uma vez que, as coxas lavadas com ácido acético a $2 \%$ mostraram um efeito inibitório significativo $(p<0,05)$ em $L$. monocytogenes em comparação com as coxas controle (lavadas com água destilada). Além disso, a vida útil das amostras lavadas com ácido acético foi prolongada em pelo menos dois dias sobre as amostras do controle lavadas com água destilada.

Shiroodi et al. (2016) utilizaram uma combinação de temperatura e água oxidante eletrolisada (EO) para atuar como pré-tratamento durante o processo de salmão defumado a frio para inativar $L$. monocytogenes.

Tango et al. (2014), avaliaram o efeito sinérgico da água eletrolisada com leve acidez e ácido fumárico na inativação de mesófilos, Staphylococcus aureus, Listeria monocytogenes, Escherichia coli O157: H7 e Salmonella Typhimurium em carne bovina fresca, além de estudar a vida de prateleira e qualidade sensorial. Concluiu que tratamento combinado mostrou maior efeito bactericida e prazo de validade prolongado em comparação com os demais tratamentos: somente água eletrolisada com leve acidez ou somente água eletrolizada com forte acidez. Portanto, o efeito sinérgico da água eletrolisada com leve acidez e ácido fumárico pode ser uma tecnologia de barreira adequada, reduzindo as bactérias na carne fresca, aumentando substancialmente a segurança microbiana e diminuindo o crescimento de patógenos durante o armazenamento. 
Estudos semelhantes ao de Tango et al. (2014) foram realizados por Mansur et al. (2015), porém, em carne suína e as conclusões foram as mesmas: o tratamento combinado de água eletrolisada com leve acidez e ácido fumárico tem potencial como um novo método para melhorar a segurança microbiana e a qualidade da carne suína fresca.

O’Neill et al. (2018) combinaram ácidos orgânicos e processamento de alta pressão hidrostática (HPP) para estender a vida útil de salsichas e presunto cozido com menor teor de sal.

O processamento de alta pressão hidrostática (HPP) é usado na indústria de alimentos para aumentar a segurança e estender o prazo de validade dos alimentos. As vantagens de HPP sobre o processamento térmico inclui redução de danos causados pelo calor, menor tempo de processamento, a preservação do frescor, textura, cor e de vitamina C (VEGA-GALVEZ et al., 2011).

Segunado Hugas et al. (2002), o HHP é uma ferramenta poderosa para controle dos riscos associados a Salmonella spp. e Listeria monocytogenes em carne crua ou marinada.

Embora uma redução drástica na viabilidade microbiana seja obtida imediatamente após a aplicação dos tratamentos HPP, sob condições favoráveis, as bactérias lesadas podem se recuperar. Jofré et al. (2010), avaliaram a inativação e recuperação de cinco linhagens de Listeria monocytogenes, Salmonella enterica e Staphylococcus aureus submetidas a pressões de 400, 600 e 900 MPa sob condições estressantes e não estressantes em meio complexo. Após o tratamento com HPP, não apenas cepas de $S$. aureus, mas também várias repetições das cepas de $L$. monocytogenes e $S$. enterica foram recuperadas durante a incubação subsequente sob condições favoráveis. No entanto, observaram que quando o HPP foi combinada com baixo $\mathrm{pH}$ e nitrito, a viabilidade das células de $S$. aureus pressurizadas diminuiu progressivamente. Como as bactérias patogênicas podem se recuperar mesmo após a aplicação de níveis muito altos de pressão, a combinação de HPP com outras barreiras para o crescimento microbiano, intrinsecamente presentes no produto alimentício ou extrinsecamente aplicadas, pode ser necessária para garantir a eficácia de tecnologias voltadas à redução de patógenos e extensão do shelf life.

Duranton et al. (2012), com seus estudos, demonstraram a existência de sinergia entre alta pressão e sal ou nitrito para a fabricação de produtos cárneos. Investigaram o crescimento de bactérias ácido láticas na carne suína durante o 
armazenamento, após uma quebra de cadeia de frio. Os tratamentos de alta pressão a $350 \mathrm{MPa}$ foram combinados com a adição de sal ou nitrito de sódio. Resultados interessantes foram observados para as bactérias do ácido láctico das amostras salgadas. Enquanto o processamento de sal ou $350 \mathrm{MPa}$ por si só não foi suficiente para retardar o crescimento destas bactérias até ao final do armazenamento, o tratamento de combinação resultou em contagens microbianas baixas (abaixo de 2 $\log$ UFC/g) no final da armazenagem.

Ghabraie et al. (2016) combinaram diversas tecnologias para preservação de linguiça suína fresca, o objetivo do estudo foi desenvolver formulações para reduzir o crescimento de $L$. monocytogenes, contendo óleos essenciais, nisina, nitrito e sais de ácidos orgânicos. Essa combinação resultou numa redução de $L$. monocytogenes em mais de 2,6 e 1,5 log UFC/g linguiça em comparação com o controle.

Ščetar et al. (2013), investigaram o shelf life de linguiças fermentadas secas fatiadas durante $o$ armazenamento a diferentes temperaturas e diferentes composições de embalagens laminadas foram utilizadas para embalagem a vácuo e nitrogênio $\left(100 \% N_{2}\right)$. A qualidade sensorial limitou o prazo de validade das salsichas fermentadas secas fatiadas antes dos efeitos limitantes da produção e antes da proliferação microbiana ocorrer. A embalagem da atmosfera de nitrogênio permitiu um armazenamento mais longo (> 120 dias) do que o vácuo (95 dias) embalados linguiças fermentadas a $4{ }^{\circ} \mathrm{C}$. Uma relação negativa foi encontrada entre aw e $\mathrm{pH}(-0.9071)$ e é possivelmente causada pela dissociação do ácido. Isso pode explicar o aumento do $\mathrm{pH}$ observado durante $\mathrm{o}$ armazenamento. Durante $\mathrm{o}$ armazenamento, $\mathrm{pH}$ e aw não foram significativamente $(P>0,05)$ afetados por material de embalagem (laminados com baixo teor de oxigênio) e método (vácuo e 100\% de N2), enquanto a temperatura e os dias de armazenamento apresentaram efeito significativo $(P<0,05)$. Todas as amostras, independentemente do material de embalagem e / ou método, alcançaram uma vida útil de 15 dias a $37^{\circ} \mathrm{C}$.

Thomas et al. (2008) desenvolveram linguiças shelf stable utilizando tecnologia de barreira e sua qualidade foi avaliada durante o armazenamento a temperatura ambiente $\left(37 \pm 1^{\circ} \mathrm{C}\right)$. Os obstáculos incorporados foram $\mathrm{pH}$ baixo $(\sim 5,90$, utilizando ácido láctico ( $\mathrm{LA}-0,5 \mathrm{~N}$ ) e Glucono-delta-lactona (GDL-0,1\%), baixa atividade de água ( 0,93, usando proteína de soja texturizada-3\%), embalagem a vácuo e pós reaquecimento do pacote $\left(90^{\circ} \mathrm{C}\right)$. Foi também estudada a imersão em solução de 
sorbato de potássio antes da embalagem a vácuo. O reaquecimento aumentou o pH das salsichas em 0,17 unidades, contra 0,11 unidades nos controles. $O$ tratamento com obstáculos reduziu a deterioração durante o armazenamento, como indicado pelos valores de $\mathrm{pH}$, TBARS (substâncias que reagem com ácido tiobarbitúrico) e tirosina. Cerca de 1 log de redução na contagem total de placas foi observada com os diferentes obstáculos, assim como reduções nas contagens de coliformes, anaeróbios, lactobacilos e Staphylococcus aureus. $\mathrm{O} \mathrm{pH}, \mathrm{a}_{w}$ e reaquecimento inibiram crescimento de levedura e mofo até o dia 3, enquanto imersão adicional em $1 \%$ de solução de sorbato de potássio inibiu o seu crescimento ao longo dos 9 dias de armazenamento. Apesar do baixo apelo sensorial inicial, as linguiças tratadas com obstáculos apresentaram uma aceitação geral com notas que variavam de "muito boa" até "boa" até ao dia 6.

Chawla et al. (2006) desenvolveram vários produtos cárneos shelf stable e ready-to-use, utilizando uma combinação de barreiras (irradiação, redução da atividade da água e embalagem a vácuo). O objetivo do estudo foi examinar efeito de diferentes obstáculos em organismos como Clostridium sporogenes, $S$. aureus e $B$. cereus e demonstrar a segurança de produtos cárneos shelf stable, ou seja, que podem ser mantidos à temperatura ambiente em embalagem selada, não necessitando portanto, de refrigeração. O resultado mostrou a sensibilidade à radiação (valores de $D_{10}$ ) de $S$. aureus, $C$. sporogenes e $B$. cereus em kebabs de carneiro era de 0,36, 3,0 e 0,29 kGy respectivamente. O tratamento com radiação (2,5 kGy) resultou na eliminação completa de $10^{6}$ UFC inoculados de $S$. aureus e B. cereus mas não de $C$. Sporogenes. A atividade da água $\left(\mathrm{a}_{w}\right)$ de 0,85 e a embalagem a vácuo de produtos impediram o crescimento de todos os três organismos inoculados nestas amostras durante 3 meses de armazenamento à temperatura ambiente.

Karthikeyan et al. (2000), aplicaram a tecnologia das barreiras para estender a vida útil de um produto de carne tradicional indiano altamente perecível, denominado keema. Os obstáculos utilizados foram a atividade da água (aw), pH, embalagens a vácuo, conservantes e tratamento térmico e os produtos foram avaliados quanto às características físico químicas, microbiológicas e sensoriais. Observaram uma diminuição na taxa de crescimento de contagens aeróbicas e anaeróbicas e inibição completa de $S$. aureus. 


\subsection{Principais microrganismos deterioradores e patogênicos em linguiças}

\subsection{1 - Bactérias Patogênicas em carnes, aves e derivados}

Muitas doenças transmitidas por alimentos estão associadas ao consumo de carne, aves e seus produtos derivados. Alguns patógenos não eram conhecidos anteriormente (novos patógenos), outros surgiram recentemente como transmitidos por alimentos (patógenos emergentes), e outros se tornaram mais potentes ou associados a outros produtos (patógenos em evolução). Muitos desses patógenos podem causar doenças graves, além de gastroenterites (MOR-MUR \& YUSTE 2010).

Os patógenos emergentes mais prevalentes e graves em carne, aves e produtos derivados são Campylobacter jejuni, Salmonella Typhimurium DT104, Escherichia coli O157: $\mathrm{H} 7$ e outros enterohemorrágicos E. coli (EHEC), Listeria monocytogenes, Arcobacter butzleri, Mycobacterium avium subsp. paratubercublosis, Aeromonas hydrophila e príons (MOR-MUR \& YUSTE 2010).

\section{Campylobacter spp}

As células da maioria das espécies de Campylobacter destacam-se pela forma de bacilos curvos, espiralados, muito finos e compridos $(0,2 \mathrm{~nm}$ a $0,5 \mathrm{~nm}$ de largura $\mathrm{e}$ 0,5 e $5 \mathrm{~nm}$ de comprimento). São Gram-negativos e moveis por um único flagelo polar que apresenta de duas a três vezes o comprimento da célula. O flagelo é responsável pelo seu movimento característico em forma de saca-rolha ou vaivém. Em culturas jovens é possível a observação da morfologia semelhante a "asa de gaivota". Não formam esporos, mas em culturas envelhecidas adquirem uma morfologia cocoide correspondente a formas não cultiváveis. São quimiorganotróficos e não fermentam nem oxidam açúcares, obtendo energia a partir de aminoácidos ou de componentes intermediários do ciclo do ácido tricarboxilico (SILVA et al., 2017).

São microaerófilos, requerendo baixa tensão de oxigênio para sua multiplicação. O crescimento é inibido quando a concentração de O2 é menor que 3\% e maior que $15 \%$, sendo a concentração ideal de $5 \%$. Além disso, são também capnofílicos, ou seja, requerem cerca de 10\% de CO2 para sua multiplicação (SILVA et al., 2017). 
Campylobacter spp estão presentes em animais de sangue quente, várias especies foram isoladas nas carcaças e nas fezes de frangos, nas carcaças e nas fezes de ovinos, em perus e em várias carnes vermelhas (FRAZIER, 1993). No entanto, o risco para diferentes países varia de acordo com o controle de medidas e práticas implementadas ao longo da cadeia, desde a produção primária até o produto final (FAO/WHO, 2009).

Campylobacter jejuni é uma das principais causas de doença bacteriana associada a alimentos. O sorotipo 0:19 e outros sorotipos são agentes etiológicos comuns da síndrome de Guillain-Barré, uma neuropatia devido à resposta auto-imune (MOR-MUR \& YUSTE 2010).

Estima-se que Campylobacter jejuni seja a terceira principal causa bacteriana de doenças transmitidas por alimentos nos Estados Unidos. Certos vírus são a maior causa conhecida de doenças transmitidas por alimentos (FDA, 2012).

Há estudos que mostram que o congelamento reduz a contaminação microbiológica significativamente. Boysen \& Rosenquist (2009) congelaram a superfície do peito de frango, pelo congelamento contínuo com $\mathrm{CO}_{2}$, o que proporcionou uma redução em Campylobacter spp de 0,42 Log (estatisticamente significativa).

\section{Salmonella spp}

A Salmonella é um gênero da família Enterobacteriaceae. São gramnegativas, anaeróbias facultativas, não formam esporos e têm forma de bastonetes curtos (1 a $2 \mu \mathrm{m}$ ). A maioria das espécies é móvel, com flagelos peritríquos; $S$. gallinarum e $S$. pullorum não são móveis. A temperatura ótima de crescimento é de aproximadamente $38^{\circ} \mathrm{C}$. Como não formam esporos, são relativamente termossensíveis, podendo ser destruídas a $60^{\circ} \mathrm{C}$, por 15 a 20 minutos (FORSYTHE, 2002).

O reservatório principal de Salmonella é o trato intestinal do homem e animais, de onde se dissemina pelo ambiente, ar, alimentos, rações, solos e águas. Embora seu habitat primário seja o trato intestinal, estes organismos podem ser encontrados em outras partes do corpo de tempos em tempos (JAY, 1996;).

Salmonella causa dois tipos de doença: (1) doença gastrintestinal, que causa náuseas, vômitos, diarréia, cólicas e febre, com sintomas que geralmente duram alguns dias e desaparecem em uma semana. Em pessoas saudáveis, os sintomas 
geralmente desaparecem sozinhos, mas pode ocorrer artrite em longo prazo; (2) doença tifóide causa febre alta, diarreia ou prisão de ventre, dores de cabeça e letargia (sonolência ou lentidão) e, por vezes, erupção cutânea. É uma condição muito séria; até $10 \%$ das pessoas que não recebem tratamento podem morrer (FDA, 2012).

\section{Listeria monocytogenes}

Listeria monocytogenes é um bastonete microaerófilo (ou facultativo anaeróbio), que não forma esporos, medindo de 0,4 a $0,5 \mu \mathrm{m}$ de diâmetro e de $0,5 \mathrm{a}$ $2 \mu \mathrm{m}$ de comprimento. Em culturas velhas de 3 a 5 dias, é comum observar-se, ao microscópio, longos filamentos ((SILVA et al., 2017).

Muitos alimentos estão associados a $L$. monocytogenes. Os exemplos incluem leite cru, leite pasteurizado inadequadamente, queijos (particularmente queijos moles), sorvetes, vegetais crus, aves e carnes cruas (todos os tipos), linguiças fermentadas de carne crua, defumados peixe e outros frutos do mar. $L$. monocytogenes pode crescer em temperaturas refrigeradas, o que torna este organismo um problema particular para a indústria alimentícia (FDA, 2012).

Embora o número de pessoas infectadas pela Listeria de origem alimentar seja comparativamente pequeno, esta bactéria é uma das principais causas de morte por doenças transmitidas por alimentos. Pode causar duas formas de doença. Pode-se variar desde sintomas leves a intensos de náuseas, vômitos, dores, febre e, às vezes, diarréia, e geralmente desaparece por si só. A outra forma mais mortal ocorre quando a infecção se espalha pela corrente sanguínea para o sistema nervoso (incluindo o cérebro), resultando em meningite e outros problemas potencialmente fatais. As mulheres grávidas são mais suscetíveis à infecção por Listeria do que a maioria das outras pessoas e, embora geralmente se recuperem, seus bebês geralmente não sobrevivem (FDA, 2012).

\section{Escherichia coli}

E. coli é o principal microrganismo aeróbio facultativo do trato intestinal de homens e animais de sangue quente, portanto indicativo de contaminação fecal, direta ou indireta de águas e alimentos (FORSYTHE, 1989).

Normalmente as cepas que colonizam o intestino humano são simples comensais. Entretanto dentro da espécie existem algumas cepas extremamente patogênicas que causam distintas síndromes diarreicas (ICMSF, 1996). 
Atualmente, existem seis grupos patogênicos reconhecidos: $E$. coli enterotoxigênica (ETEC), E. coli enteropatogênica (EPEC), E. coli enterohemorrágica (EHEC), E. coli enteroinvasora (EIEC), E. coli enteroagregativa (EAEC) e E. coli difusamente aderente (DAEC). Destes, os primeiros quatro grupos são bem conhecidos por serem transmitidos por alimentos ou água contaminados; EHEC, especialmente, são frequentemente implicados nos principais surtos de origem alimentar em todo o mundo (FORSYTHE, 2002).

A maioria das bactérias $E$. coli é inofensiva, mas algumas produzem uma toxina (toxina Shiga) que pode causar doenças graves, incluindo diarréia sanguinolenta, problemas de coagulação sanguínea, insuficiência renal e morte. Nem todas as E. coli produtoras de Shiga podem causar esses problemas, mas o subconjunto chamado E. coli enterohemorrágica (EHEC) pode. Os surtos de EHEC foram atribuídos a muitos tipos de alimentos, por exemplo, carnes moídas, leite não pasteurizado, suco de frutas não pasteurizado, alface, espinafre, brotos e, mais recentemente, massa de biscoito congelada fabricada comercialmente (FDA, 2012).

Embora os ruminantes, e particularmente o gado, sejam considerados como o principal reservatório para STEC (CAPRIOLI; MORABITO; BRUGERE; OSWALD, 2005; KARMALI et al., 2010), há evidências para algumas aves (selvagens), suínos, cães e cavalos.

Entre os anos de 2010 e 2011, na Holanda, Mughini-Gras et. al, usando uma atribuição de fonte combinada e análise de caso-controle, determinaram as contribuições relativas de quatro fontes pecuárias: bovinos, pequenos ruminantes, suínos e frangos de corte para infecções humanas por STEC. Foram avaliadas também as dietas, contato com animais e perfil sócio-econômico-demográfico. Ambos os modelos identificaram o gado como a principal fonte de infecção por STEC, representando 48,6\% (IC95\%: 44,4\% -52,6\%) dos 1.183 isolados humanos na DM e $53,1 \%$ (IC95\%: $41,7 \%$ a $63,6 \%$ ), destes mesmos isolados no $\mathrm{mHM}$. Os pequenos ruminantes foram estimados como a segunda fonte mais importante: o $\mathrm{mDM}$ e o $\mathrm{mHM}$ atribuíram 23,5\% (95\% Cl: $20,4 \%-26,8 \%$ ) e $25,4 \%$ (95\% Cl: $17,2 \%-35,7 \%)$ dos isolados humanos a pequenos ruminantes, respectivamente. Estima-se que os suínos respondam por $12,5 \%$ (95\% Cl: 9,0\% -16,5\%) das infecções humanas pelo mDM e por $5,7 \%(2,2 \%-11,1 \%)$ deles pelo $\mathrm{mHM}$. A fonte menos importante foi estimada em aves tanto pelo $\mathrm{mDM}(2,7 \%, 95 \% \mathrm{Cl}: 1,4 \%-5,1 \%)$ quanto pelo $\mathrm{mHM}(3,1 \%, 95 \% \mathrm{Cl}$ : $1,1 \%-6,9 \%)$. A fonte dos restantes $12,8 \%$ de isolados humanos eram desconhecidos. 


\section{Outros Patógenos Emergentes}

O Arcobacter butzleri é um potencial patógeno de origem alimentar e foi isolado de carne de aves, carne e produtos crus; mas o seu papel na causa da doença humana não é totalmente compreendido. Mycobacterium avium subsp. paratuberculose pode ser transmitida pela ingestão de carne crua e processada; o organismo pode contribuir para a doença de Crohn, uma enterite intestinal crônica. Carne bovina, suína, ovina e / ou aves foram relatadas como fontes de infecção para os organismos acima mencionados, mas não foram geralmente associadas a surtos de doenças de alguns dos patógenos (MOR-MUR; YUSTE, 2010).

\subsubsection{Microrganismos Deteriorantes}

Microrganismos deteriorantes são aqueles que causam alguma alteração indesejável nos alimentos, de ordem química: cor, odor, sabor, textura e aparência. Os principais microrganismos envolvidos na deterioração das características sensoriais dos derivados cárneos são as bactérias, leveduras e os bolores.

As bactérias ácido-láticas (BAL), ou bactérias láticas, são uma das principais responsáveis pela produção de sabor e aromas indesejáveis em derivados cárneos. No entanto, são bastante empregadas na produção de alimentos, como leites fermentados, iogurtes e queijos, bem como no processamento de carnes, bebidas alcoólicas e vegetais.

As BAL são um grupo de microrganismos Gram-positivos, catalase negativos, não formadores de esporos e que geralmente crescem sob condições microaerófilas ou estritamente anaeróbicas. Os mais importantes gêneros são: Streptococcus, Lactobacillus, Leuconostoc e Lactococcus.

Embora as BAL englobem diversos gêneros, elas são agrupadas como homofermentativas ou heterofermentativas, com base no produto final da sua fermentação. As homofermentativas produzem ácido lático como principal produto da fermentação da glucose. As heterofermentativas, além do ácido lático, formam outras substâncias, como dióxido de carbono, ácido acético e etanol, a partir da fermentação da glucose (CARR et al., 2002). 
As bactérias lácticas são essencialmente mesófilas, com algumas linhagens termófilas, sendo capazes de crescer num intervalo de temperaturas de 5 a $45^{\circ} \mathrm{C}$. Têm a capacidade de crescer a pH de 3,8 e são proteolíticas fastidiosas em relação a alguns aminoácidos. Também produzem vários fatores antimicrobianos, incluindo ácidos orgânicos, peróxido de hidrogénio, nisinas, bacteriocinas diacetilo e acetaldeído (FORSYTHE, 2002).

\subsubsection{Microrganismos Indicadores}

A utilização de indicadores higiênicos sanitários visa avaliar a qualidade do alimento. Com isto, microrganismos indicadores são grupos ou espécies de microrganismos que, quando presentes, podem fornecer informação sobre contaminação de origem fecal, presença de patógenos ou deteriorantes, indicando também condições sanitárias durante processamento, produção ou armazenamento do produto alimentício. O grupo de coliformes (Escherichia, Enterobacter, Citrobacter e Klebsiella) apresenta por habitat o trato gastrointestinal do homem e dos animais. Na contagem de coliformes diferenciam-se dois grupos: coliformes totais e coliformes fecais, o primeiro grupo conhecido como indicadores da qualidade sanitária ou da contaminação de alimentos, evidenciando falhas nas práticas de higiene e sanitização e o segundo grupo, utilizados como indicadores de contaminação fecal, denotando condições higiênico-sanitárias deficientes. A determinação de ambos os grupos indica a qualidade higiênica em relação a procedimentos de abate, manipulação e armazenamento (JAY, 1994).

Os microrganismos aeróbios mesófilos constituem o grupo que inclui a maioria de microrganismos acidificantes. Estes têm sido utilizados como indicadores microbiológicos de qualidade, proporcionando uma ideia sobre o tempo de vida útil, apontando matérias-primas contaminadas ou processamento insatisfatório, bem como, tempo e temperatura inadequados durante produção ou armazenamento. Por outro lado, grande número de bactérias patogênicas, de origem alimentar, são mesófilas (crescimento de $30^{\circ} \mathrm{C}$ a $40^{\circ} \mathrm{C}$ ). Assim, altas contagens de mesófilos revelam condições favoráveis para o desenvolvimento de patógenos (e.g. Clostridium botulinum, Yersinia enterocolitica, Escherichia coli, Listeria monocytogenes), além de estarem associados com alterações organolépticas do produto (acima de $10^{6} \mathrm{UFC} / \mathrm{g}$ ). Ainda, sua determinação é usada no monitoramento das Boas Práticas de Fabricação (BPF). 
O gênero Escherichia, juntamente com os gêneros Enterobacter, Citrobacter e Klebsiella, formam o grupo denominado coliforme (SILVA \& JUNQUEIRA, 1995). O habitat das bactérias que pertencem ao grupo coliforme é o trato intestinal do homem e de outros animais (PARDI et al., 1995), entretanto, espécies do gênero Enterobacter, Citrobacter e Klebsiella podem persistir por longos períodos e se multiplicarem em ambientes não fecais. O índice de coliformes totais é utilizado para avaliar as condições higiênicas (DELAZARI, 1998), sendo que altas contagens significam contaminação pós-processamento, limpezas e sanitizações deficientes, tratamentos térmicos ineficientes ou multiplicação durante o processamento ou estocagem. $O$ índice de coliformes fecais empregado como indicador de contaminação fecal, ou seja, de condições higiênico-sanitárias deficientes levando-se em conta que a população deste grupo é constituída de uma alta população de E. coli (PARDI et al., 1995), pode indicar outros patógenos internos (SIQUEIRA, 1995). Em geral as bactérias do grupo coliformes são prejudiciais para os alimentos, onde sua presença determina inutilidade dos mesmos (FRAZIER, 1976). O grupo coliforme é constituído de uma microbiota grandemente associada à carne de aves. Dentre elas, a E. coli normalmente alcança populações de $10^{2} / \mathrm{g}$ da carcaça sob condições normais de obtenção (DELAZARI, 1998). Franco \& Landgraf (1996) descrevem que a pesquisa dos microrganismos indicadores é utilizada para avaliar a qualidade microbiológica dos alimentos e apontar riscos de contaminações de origem fecal com a provável presença de patógenos ou deterioração do alimento, além das indicações higiênico-sanitárias durante 0 processamento, a produção e o armazenamento.

\subsection{Descrição da Empresa em estudo}

A empresa "A" é uma companhia global de alimentos, tem sede no Brasil e mais de 80 anos de história. Por meio de um portfólio de mais de 4 mil produtos, está presente na vida de consumidores de cerca de 150 países e responde por 16,3\% do comércio mundial de aves. É uma empresa que possui o propósito de alimentar o mundo.

Foi eleita a empresa em Aves e Suínos, do prêmio Melhores do Agronegócio (Globo Rural). Ocupa a 13aㅡ posição entre 1.500 empresas do Ranking Empresas Mais (O Estado de São Paulo) e o 10ํ lugar entre as 1.000 Maiores, além 
do $12^{\circ}$ em Melhores de Bens de Consumo da lista de Melhores e Maiores (REVISTA EXAME, 2018).

Trabalha em um modelo de produção integrada, com operações que vão do campo à mesa e abrangem mais de 100 unidades próprias (somando fábricas, escritórios e centros de distribuição). Desde a compra de grãos e a produção de ração animal até o supermercado, passando por criação de animais, processamento de alimentos, distribuição e venda, conta com equipes próprias e uma ampla rede de produtores integrados, parceiros logísticos e fornecedores de serviços e matériasprimas.

São mais de 105 mil pessoas, pertencentes a mais de 40 nacionalidades, que falam cerca de 20 idiomas. Busca traduzir essa multiculturalidade em um ambiente interno aberto à inovação e à diversidade, conectando valores, princípios e visão de futuro.

Preza por um modelo organizacional que permita uma governança moderna, ágil e capaz de responder aos desafios dos últimos anos. Companhia de capital aberto desde os anos 1980 e, em 2006, ingressou no Novo Mercado da bolsa brasileira (B3). Por isso, segue as melhores práticas, com foco na ética, na transparência, na equidade e na responsabilidade corporativa.

Com o compromisso de oferecer produtos de qualidade que contribuam para uma vida saudável se traduz em diversas iniciativas, incluindo a gestão do ciclo produtivo, controles na cadeia de distribuição e nos pontos de venda e melhorias em formulação e desenvolvimento de produtos. Impactos e ocorrências relacionados à saúde e à segurança do consumidor são considerados críticos, e podem afetar diretamente a reputação e a imagem da Companhia, além de gerar reflexos nos resultados financeiros com reprocesso, destruição de produtos e custos ligados ao recolhimento, à não venda e a problemas de qualidade.

Em respeito à segurança dos alimentos, a companhia adota como referência requisitos internacionais de qualidade para desenvolvimento de processos por toda sua cadeia produtiva e de distribuição. A Política Interna de Qualidade estabelece procedimentos-padrão, medidas e critérios que abrangem todos os produtos e as unidades da empresa, afim de reduzir ou eliminar todos os riscos sanitários, microbiológicos, químicos, físicos ou legais. Hoje, 100\% dos produtos são avaliados no programa APPCC (Análise de Perigos e Pontos Críticos de Controle), que é uma sistemática onde identifica perigos específicos e medidas de controle, 
garantindo a segurança do alimento, podendo ser aplicado ao longo da cadeia, desde a produção primária até o consumo final.

Além disso, a empresa possui uma sistemática de auditorias, denominada Auditorias do Sistema da Qualidade, que tem o objetivo de garantir a aderência dos processos internos aos requisitos legais e aos padrões de clientes e de certificação e viabilizar a análise crítica e a melhoria contínua do sistema da qualidade.

A companhia possui uma sistemática de certificações implantados e auditados periodicamente, envolvendo diversas etapas da cadeia, desde o campo, produção de alimentos até os laboratórios. Atualmente $100 \%$ das unidades produtoras recebem auditorias externas e de acordo com o mercado de destino possuem certificações de qualidade que são consideradas diferenciais nos mesmos, como BRC, IFS, Global-GAP, AloFree, Certified Humane e ISO 17025:2017, entre outras. Adicionalmente, a companhia é auditada externamente por diversos mercados e clientes, além de órgãos competentes brasileiros - Ministério da Agricultura, Pecuária e Abastecimento (MAPA) e Agência Nacional de Vigilância Sanitária (Anvisa), assegurando assim seu compromisso com requisitos legais e de clientes.

Em 2017, mais uma conquista, no que tange a evolução da Companhia em relação à segurança dos alimentos, foi eleito um representante da empresa como membro do Conselho do Global Food Safety Initiative (GFSI), grupo internacional colaborativo sem fins lucrativos liderado por especialistas em food safety ao redor do mundo, atuando na cadeia varejista, indústria e empresas de food service. Sua missão é promover a melhoria contínua dos sistemas de gestão de food safety, para garantir a confiança na entrega de alimentos seguros aos consumidores. 


\section{Referências}

1. ABREU, A.; REQUEIJO, J. G.; CALADO, J. Implementation of statistical process control in a bottling line in winery industry. Millenium, v. 7, p. 23-37. 2018.

2. AHMED, M.; AHMAD, N. An application of Pareto analysis and cause-and-effect diagram (CED) for minimizing rejection of raw materials in lamp production process. Management Science and Engineering, v. 5(3), p. 87-95. 2011.

3. ASSOCIAÇÃO BRASILEIRA DE PROTEÍNA ANIMAL. (2019). Exportações de carne suína crescem 5,65\% em 2019. Disponível em: < http://abpabr.com.br/noticia/exportacoes-de-carne-suina-crescem-565-em-2019-2709> Acesso em: 01 mai. 2019.

4. BAKER, J.A., TAVARES, R.J., MOTH, V.M., MORAIS, L.M. de. Reject analysis of Cement bags in the cement CSN. Cad. UniFOA Spec. Ed. Prod. Eng. p. 29-43. 2014.

5. BRASIL, 2017, Ministério da Agricultura, Pecuária e Abastecimento. Departamento Nacional de Inspeção de Produtos de Origem Animal. Regulamento da Inspeção Industrial e Sanitária de Produtos de Origem Animal RIISPOA. Brasília: MAPA, 2017. 154 p. Aprovado pelo Decreto oㅜ 9.013, de 29 de março de 2017.

6. BRASIL, 2001, RDC nº12 de 02 de janeiro de 2001 do Ministério da Saúde Anexo I - Padrões Sanitários Microbiológicos para Alimentos.

7. BRASIL, 2000, Ministérios da Agricultura, Pecuária e Abastecimento, Instrução Normativa $n^{\circ} 4$ de 31 de março de 2000 da SDA e DIPOA - Anexo III Regulamento Técnico para Fixação de Identidade e Qualidade de Linguiça.

8. CAMPOS, V. F., Gerenciamento da Rotina do Trabalho do Dia-a-Dia. 8. ed. Belo Horizonte: INDG Tecnologia e Serviços Ltda, 2004. 266p.

9. CARPENTER, C.; SMITH, J.; BROADBENT, J. Efficacy of washing meat surfaces with $2 \%$ levulinic, acetic, or lactic acid for pathogen decontamination and residual growth inhibition. Meat Science, v. 88(2), p. 256-260. 2011.

10. CARR, F. J.; CHILL, D.; MAIDA, N. The acid lactic bacteria: A literature survey. Critical Reviews in Microbiology, v. 28, n. 4, 2002.

11. CHAWLA, S. P.; CHANDER, R.; SHARMA, A. Safe and shelf-stable natural casing using hurdle technology, Food Control. v. 17, p. 127-131. 2006. 
12. CHOKKLINGAM, B.; RAJA, V.; ANBURAJ. J.; IMMANUAL, R.;

DHINESHKUMAR, M. Investigation of Shrinkage Defect in Castings by

Quantitative Ishikawa Diagram, Archives of Foundry Engineering, v. 17(1), p. 174-178. 2017.

13.COX, M.; SANDBERG, K. Modeling Causal Relationships in Quality Improvement, Curr Probl Pediatr Adolesc Health Care, v. 48, p. 182-185. 2018.

14.DALGIÇ, C.; VARDIN, H.; BELIBAÄŸLI, K. Improvement of Food Safety and Quality by Statistical Process Control (SPC) in Food Processing Systems: A Case Study of Traditional Sucuk (Sausage), Processing, quality control of herbal medicines and related areas, Y. Shoyama, Ed.(2011).

15.DJEKIC, I. et al. One approach in using multivariate statistical process control in analyzing cheese quality, Mljekarstvo, v.65(2), p. 91-100. 2015.

16.DJEKIC, I.; SMIGIC, N.; TOMIC, N.; RAJKOVIC, A. Statistical Process Control in Serbian Food Packaging, International Journal for Quality Research, v. 8(3), p. 323-334. 2014.

17.DOSSIE LINGUIÇA. Disponível em: < http://www.perdigao.com.br/papo-defamilia/dossie-linguica/4409/>. Acesso em: 07 abr. 2019.

18. DUDIN, M. N., et al. The Deming Cycle (PDCA) Concept as a Tool for the Transition to the Innovative Path of the Continuous Quality Improvement in Production Processes of the Agro-Industrial Sector. European Research Studies Journal, Volume XX, Issue 2B, p. 283-293, 2017.

19.DURANTON, F.; GUILLOU, S.; SIMONIN, H.; CHÉRET, R.; LAMBALLERIE, M. Combined use of high pressure and salt or sodium nitrite to control the growth of endogenous microflora in raw pork meat. Innovative Food Science and Emerging Technologies, v. 16, p. 373-380. 2012.

20.DZIUBA, S. T.; JAROSSOVÁ, M. A.; GOŁĘBIECKA, N. Applying the 5 Why method to verification of non-compliance causes established after application of the Ishikawa diagram in the process of improving the production of drive halfshafts. Production Engineering Archives, v. 2, p. 16-19. 2014.

21. EXAME. 2018. Melhores e Maiores: As 1000 maiores empresas do Brasil. Disponível em: https://exame.abril.com.br/edicoes/melhores-maiores-2018/. Acesso em: 26 mar. 2019. 
22. FAO/WHO. Activities on Risk Assessment of Microbiological Hazards in Food Risk Assessment: Salmonella and Campylobacter in chicken meat. Hazard Identification and Hazard Characterization of Salmonella in Broilers and Eggs. Rome, Italy, 2009.

23. FOOD AND DRUG ADMINISTRATION. Bad Bug Book, Foodborne Pathogenic Microorganisms and Natural Toxins - Salmonella species. 2. ed. 2012, p. 9-13. 24. FOOD AND DRUG ADMINISTRATION. Bad Bug Book, Foodborne Pathogenic Microorganisms and Natural Toxins - Campylobacter jejuni.2. ed. 2012, p. 1417

25. FOOD AND DRUG ADMINISTRATION. Bad Bug Book, Foodborne Pathogenic Microorganisms and Natural Toxins - Pathogenic Escherichia coli Group. 2. ed. 2012, p. 68-81.

26. FOOD AND DRUG ADMINISTRATION. Bad Bug Book, Foodborne Pathogenic Microorganisms and Natural Toxins - Listeria monocytogenes, 2. ed. 2012, p. 99-103.

27.GARRIGA, M.; AYMERICH, M. T.; COSTA, S.; MONFORT, M.; HUGAS, M. Bactericidal synergism through bacteriocins and high pressure in a meat model system during storage. Food Microbiology, v.19, p. 509-518. 2002.

28. GHABRAIE, M.; VU, K, D.; HUQ, T.; KHAN, A.; LACROIX, M. Antilisterial effects of antibacterial formulations containing essential oils, nisin, nitrite and organic acid salts in a sausage model. J Food Sci Technol, v. 53(6), p. 2625-2633. 2016.

29. GILDEH, B. S.; IZIY, A.; GHASEMPOUR, B. Estimation of $C_{p m k}$ process capability index based on bootstrap method for Weibull distribution: a case study, International Journal for Quality Research, v. 8(2), p. 255-264. 2014.

30. GLOBO RURAL. 2018. Melhores do Agronegócio: Aves e Suínos. Disponível em: https://revistagloborural.globo.com/Colunas/melhores-doagronegocio/noticia/2017/10/aves-e-suinos-brf.html. Acesso em 26 mar. 2019.

31.GONZALEZ-FANDOS, E.; HERRERA, B. Efficacy of acetic acid against Listeria monocytogenes attached to poultry skin during refrigerated storage. Foods, v. 3(3), p. 527-540.2014. 
32.JAGUSIAK-KOCIK, M.; PDCA cycle as a part of continuous improvement in the production company - a case study. Production Engineering Archives, v.14, p. 19-22, 2017.

33.JOFRÉ, A.; AYMERICH, T., BOVER-CID, S.; GARRIGA, M. Inactivation and recovery of Listeria monocytogenes, Salmonella enterica and Staphylococcus aureus after high hydrostatic pressure treatments up to $900 \mathrm{MPa}$. International Microbiology, v. 13(3), p. 105-112. 2010.

34.Karthikeyan, J.; Kumar, S.; Anjaneyulu, A. S. R.; Rao, K. H. Application of hurdle technology for the development of Caprine keema and its stability at ambient temperature, Meat Science, v.54, p. 9-15. 2000.

35. KHARBACH, M.; CHERRAH, Y.; VANDER HEYDEN, Y.; BOUKLOUZE, A. Multivariate statistical process control in product quality review assessment $-A$ case study, Annales Pharmaceutiques Françaises. v. 75(6), p. 446-454. 2017. 36. LEISTNER, L. Basic aspects of food preservation by hurdle technology. Int. J. Food Microbiol, v. 55, p. 181-186. 2000.

37. LI, S.S.; LEE, L.C. Using fishbone analysis to improve the quality of proposals for science and technology programs, Research Evaluation, v. 20 (4), p. 275-282. 2011.

38. LIM, S. A. H.; ANTONY, J.; GARZA-REYES, J. A.; ARSHED, N. Towards a conceptual roadmap for Statistical Process Control implementation in the food industry. Trends in Food Science \& Technology, v. 44, p. 117-129. 2015.

39. LIM, S. A. H.; ANTONY, J.; ARSHED, N. A. Critical Assessment on SPC Implementation in the UK Food Industry. Journal of Systemics, Cybernetics and Informatics, v. 14, p. 37-42. 2016.

40. MAHESH, B. P., PRABHUSWAMY, M. S. Process variability reduction through statistical process control for quality improvement, International Journal for Quality Research. v. 4(3), p. 193-203. 2010.

41. MANI-LOPEZ, E.; GARCÍA, H. S.; LÓPEZ-MALO, A. Organic acids as antimicrobials to control Salmonella in meat and poultry products. Food Research International, v. 45(2), p. 713-721. 2012.

42. MANSUR, A. R.; TANGO, C. N.; KIM, G.-H.; OH, D.-H. Combined effects of slightly acidic electrolyzed water and fumaric acid on the reduction of foodborne 
pathogens and shelf life extension of fresh pork. Food Control, v. 47, p. 277-284. 2015.

43. MATARAGAS, M. ; RANTSIOU, K. ; ALESSANDRIA, V. ; COCOLIN, L.

Estimating the non-thermal inactivation of Listeria monocytogenes in fermented sausages relative to temperature, $\mathrm{pH}$ and water activity. Meat Science, v. 100, p. 171-178, 2015.

44. MASSAGUER, P. R. M. Microbiologia dos Processos Alimentares. São Paulo: Livraria Varela, 2005.

45. METHA, W. Weighting for success, applying prioritization technique takes causeand-effect diagrams up a notch, Industrial Engineering, v. 4 (1), p. 45-49. 2014.

46. OLIVEIRA, J.A. de; NADAE, J.; OLIVEIRA, O.J.; SALGADO, M.H. A study on the use of quality systems, programs and tools in companies from the interior of São Paulo. Production 21, p. 708-723. 2011.

47.OMORIA, Y.; MIAKEB, K.; NAKAMURAC, H.; KAGE-NAKADAIA, E.;

NISHIKAWA, Y. Influence of lactic acid and post-treatment recovery time on the heat resistance of Listeria monocytogenes. International Journal of Food Microbiology, v. 257, p. 10-18, 2017.

48. O'NEILL, C. M.; CRUZ-ROMERO, M. C.; DUFFY G.; KERRY, J.P. Shelf life extension of vacuum-packed salt reduced frankfurters and cooked ham through the combined application of high pressure processing and organic acids. Food Packag Shelf Life, v. 17, p. 120-128. 2018.

49. PRASHAR, A. Adopting PDCA (Plan-Do-Check-Act) cycle for energy optimization in energy-intensive SMEs. Journal of Cleaner Production, v. 145, p. 277-293. 2017.

50.PIPEK, P.; HOUSKA, M.; HOKE, K.; JELENÍKOVÁ, J.; KÝHOS, K.; SIKULOVÁ, M. Decontamination of pork carcasses by steam and lactic acid. Journal of Food Engineering, v. 74(2), p. 224-231. 2006.

51.PRÍSTAVKA, M.; KOTOROVÁ, M.; SAVOV, R. Quality Control in Production Processes. Acta Technologica Agriculturae, v. 3. p 77-83. 2016.

52. RÁBAGO-REMY, D.; PADILLA-GASCA, E.; RANGEL-PERAZA, J. G. Statistical Quality Control and Process Capability Analysis for Variability Reduction of the Tomato Paste Filling Process, Industrial Engineering Management, v. 3, p. 1-7. 2014. 
53.RASO, J.; BARBOSA-CANOVAS, G. V. Nonthermal preservation of foods using combined processing techniques. Critical Reviews in Food Science and Nutrition, v. 43, p. 265-285. 2003.

54. REVISTA ESTADO DE SÃO PAULO. 2019. Ranking 1500. Disponível em: http://publicacoes.estadao.com.br/empresasmais2018/ranking-1500/. Acesso em: 26 mar. 2019.

55. REALYVÁSQUEZ-VARGAS, A.; ARREDONDO-SOTO, K. C.; CARRILOGUTIÉRREZ, T. RAVELO, G. Applying the Plan-Do-Check-Act (PDCA) Cycle to Reduce the Defects in the Manufacturing Industry: A Case Study. Appl. Sci., v. 8, 17 p. 2018.

56. RODRIGUEZ-CALLEJA, J. M.; CRUZ-ROMERO, M. C.; O'SULLIVAN, M. G.; GARCIA-LOPEZ, M. L.; KERRY, J. P. High-pressure-based hurdle strategy to extend the shelf-life of fresh chicken breast fillets. Food Control, v.25, p. 516524.2012.

57.ŠČETAR, M.; KOVAČIĆ, E.; KUREK, M.; GALIĆ , K. Shelf life of packaged sliced dry fermented sausage under different temperature, Meat Science, $v$. 93, p. 802-809. 2013.

58.SHIROODI, S. G.; OVISSIPOUR, M.; ROSS, C. F.; RASCO, B. A. Efficacy of electrolyzed oxidizing water as a pretreatment method for reducing Listeria monocytogenes contamination in cold-smoked Atlantic salmon (Salmo salar). Food Control, v. 60, p. 401-407.2016.

59.SILVA, F. V.; GIBBS, P. A. Thermal pasteurization requirements for the inactivation of Salmonella in foods. Food Research International, v. 45(2), p. 695-699. 2012.

60.SILVA, A. S.; MEDEIROS, C. F.; VIEIRA, R. K. Cleaner Production and PDCA cycle: Practical application for reducing the Cans Loss Index in a beverage company, Journal of Cleaner Production, v. 150, p. 324-338. 2017.

61.SINGH, S.; SHALINI R. Effect of Hurdle Technology in Food Preservation: A Review, Critical Reviews in Food Science and Nutrition, v. 56, p. 641-649. 2016.

62.SUÁREZ-BARRAZA, M. F.; RODRÍGUEZ-GONZÁLEZ, F. G. Cornerstone root causes through the analysis of the Ishikawa diagram, is it possible to find them?: A first research approach, International Journal of Quality and Service Sciences, p. 1-16, 2018. 
63. SUINOCULTURA INDUSTRIAL. (2019a). Carne suína fecha dezembro com 47,8 mil toneladas embarcadas. Disponível em: < https://www.suinoculturaindustrial.com.br/imprensa/carne-suina-fecha-dezembrocom-478-mil-toneladas-embarcadas/20190103-084010-0050 >. Acesso em: 07 jan.2019.

64.SUINOCULTURA INDUSTRIAL. (2019b). Exportações e custos menores podem garantir recuperação da suinocultura. Disponível em <https://www.suinoculturaindustrial.com.br/imprensa/exportacoes-e-custosmenores-podem-garantir-recuperacao-da-suinocultura/20190104-124036-B571 >. Acesso em: 07 jan.2019.

65. TAN, S. M.; LEE, S. M.; DYKES, G. A. Acetic acid induces pH independente cellular energy depletion in Salmonella enterica. Foodborne Pathogens and Disease, v. 12(3), p. 183-189. 2015.

66. TANGO, C. N.; MANSUR, A. R.; KIM, G. H.; OH, D. H. Synergetic effect of combined fumaric acid and slightly acidic electrolysed water on the inactivation of food-borne pathogens and extending the shelf life of fresh beef. Journal of Applied Microbiology, v. 117(6), p.1709-1720. 2014.

67. THOMAS, R.; ANJANEYULU, A.S.R.; KONDAIAH, N. Development of shelf stable pork sausages using hurdle technology and their quality at ambient temperature $\left(37 \pm 1^{\circ} \mathrm{C}\right)$ storage. Meat Science, v.79, p.1-12. 2008.

68. VANDENDRIESSCHE, F. Meat products in the past, today and in the future. Meat Sci., v.78, n.1-2, p.104-113, 2008.

69. VEGA-GALVEZ, A.; MIRANDA, M.; ARANDA, M.; HENRIQUEZ, K., VERGARA, J.; TABILO-MUNIZAGA, G., et al. Effect of high hydrostatic pressure on functional properties and quality characteristics of Aloe veragel (Aloe barbadensis Miller). Food Chemistry, v.129(3), p.1060-1065. 2011. 


\section{CAPÍTULO 2}




\section{CAPÍTULO 2: ARTIGO 1}

\section{AVALIAÇÃO DA QUALIDADE MICROBILÓGICA DAS LINGUIÇAS COZIDAS}

\subsection{Introdução}

A carne crua é um meio ideal para o crescimento de muitos microrganismos devido ao seu elevado teor de água (aw >0,99), e sua abundância de proteínas, peptídeos e aminoácidos. Além disso, contém glicogênio fermentável e tem um pH favorável para o desenvolvimento de muitos microrganismos $(5,5-6,5)$. Portanto, a carne crua é um produto altamente perecível e deve ser preservado (BUNCIC et al., 2014).

Durante a produção de linguiças, a moagem das matérias-primas cárneas, adição de sal, condimentos e o cozimento são as principais etapas do processamento, alterando substancialmente características das matérias-primas e da linguiça cozida. Estes são possíveis pontos de contaminação, que também podem ser pontos críticos de controle para inativação microbiana (NOOR et al., 2016).

Os microrganismos patogênicos e deteriorantes podem ser introduzidos aos produtos industrializados por matérias-primas contaminadas ou de contaminação cruzada equipamento ou manipuladores durante o processamento ou no varejo. As condições durante o processamento devem seguir atendendo as normas de Boas Práticas de Fabricação (BPF) e os perigos que podem causar algum dano ao consumidor devem ser tratados nos Programas de Análises de Perigos e Pontos Críticos de Controle (APPCC), com o objetivo de garantir a estabilidade e a segurança do alimento.

A Norma ISO 22000 define como programa de pré-requisitos (PPR) as condições básicas e atividades necessárias para manter um ambiente higiênico ao longo da cadeia produtiva de alimentos, adequadas para a produção, manuseio e provisão de alimentos seguros para o consumo humano (ISO 22.000/2006).

Os PPRs dependem do segmento da cadeia produtiva de alimentos em que a organização opera e o tipo de organização. Exemplos de termos equivalentes: Boas Práticas Agrícolas, Boas Práticas Pecuárias, Boas Práticas de Fabricação, Boas Práticas de Higiene, Práticas de Manipulação, Boas Práticas de Distribuição e Boas Práticas de Comercialização, além dos programas do Sistema da Qualidade e 
Segurança de Alimentos definidos como fundamentais pela companhia, tais como: Controle de Formulações, Procedimentos Sanitários Operacionais (PSO), Procedimentos Padrão de Higienização Operacional (PPHO), Controle de Alergênicos, Calibração e controle de Instrumentos, Rastreabilidade, Controle de Produto Não conforme, entre outros (ISO 22000/2006).

Em particular, para produção de carne de aves e de suínos, é essencial que a higiene seja mantida durante as operações de abate, de acordo Princípios APPCC e requisitos de BPF para reduzir o risco de contaminação da carcaça.

Os microrganismos indicadores são úteis para avaliar a qualidade microbiológica dos alimentos, fornecendo informações sobre o grau de contaminação dos alimentos e condições higiênicas durante o processamento e armazenamento (SANTOS, 2009).

A contagem Total de Aeróbios Mesófilos em placas, (Aerobic Plate Count), também denominada Contagem Padrão em Placas, é o método mais utilizado como indicador geral de populações bacterianas em alimentos. Não diferencia tipos de bactéria, sendo utilizada para se obter informações gerais sobre a qualidade de produtos, práticas de manufatura, matérias-primas utilizadas, condições de processamento, manipulação e vida de prateleira. Dependendo da situação, pode ser útil na avaliação da qualidade, porque populações altas de bactérias podem indicar deficiências na sanitização ou falha no controle do processo ou dos ingredientes (SILVA et al., 2017).

Este estudo foi realizado em uma empresa de grande porte, denominada de empresa "A", localizada no interior do Estado de Minas Gerais.

\subsection{Objetivos}

Realizar análises de mesófilos na superfície e no interior do gomo de linguiças cozidas e defumadas para entender se as condições de processamento são adequadas. Com isso, forão realizadas as seguintes análises: (1) análises microbiológicas do produto antes do cozimento, com o objetivo de realizar um paralelo à qualidade do processamento até a entrada para o cozimento e a qualidade da matéria-prima utilizada; (2) análises microbiológicas após o cozimento, para entender se o mesmo foi eficiente; (3) análises microbiológicas após resfriamento para verificar se não há contaminação cruzada durante este processo. 


\subsection{Materiais e métodos}

\subsection{1 - Preparo das amostras}

Todos os experimentos foram realizados nas instalações da Empresa " $A$ " (fábricas e laboratórios).

Uma quantidade de 5 gomos era retirada diretamente da linha de produção da empresa "A", foi moído fino em discos de aproximadamente $5 \mathrm{~mm}$ de diâmetro por 2 ou 3 vezes, até que a amostra se apresentasse como uma massa homogênea. Durante os meses de maio a outubro isso foi repetido 30 vezes, totalizando $n=30$ amostras, para cada ponto que se desejava estudar: antes do cozimento, após cozimento e após resfriamento.

\subsubsection{1 - Determinação de bactérias Mesófilas Aeróbias e Anaeróbias Facultativas}

O método utilizado foi para determinação quantitativa pela técnica de contagem em profundidade utilizando placas de Petrifilm ${ }^{\mathrm{TM}} 3 \mathrm{M}^{\mathrm{TM}}$ para Contagem de microrganismos aeróbios mesófilos - AOAC 990.12 (AOAC, 2016).

Foram preparadas diluições de 1:10, 1:100 e 1:1000 e transferidas alíquotas de $1 \mathrm{~mL}$ de cada diluição para placas de Petri (AC - para contagem de aeróbios e RAC - para contagem rápida de aeróbios). As placas de Petrifilm AC foram incubadas não invertidas em estufa a $35^{\circ} \mathrm{C} \pm 1$ por 48 horas $( \pm 2 \mathrm{~h})$ e as placas de Petrifilm RAC foram incubadas não invertidas em estufa a $35^{\circ} \mathrm{C} \pm 1$ por 24 horas $( \pm 2 h)$.

O resultado foi medido pela contagem do número de colônias multiplicando pelo fator de diluição, ou seja, representando o número de bactérias lácticas por grama da amostra analisada, expressos por log UFC/g.

\subsubsection{Determinação de microrganismos viáveis em superfícies (swab)}

A técnica do esfregaço ou contato em superfície aplica-se a alimentos cuja contaminação é predominantemente superficial e também para as superfícies de equipamentos, mesas, utensílios, mãos e embalagens.

Para superfícies dos gomos, foram preparados tubos com volume de 10 $\mathrm{mL}$ de água peptonada tamponada (APT) e foi utilizado um molde estéril de $10 \mathrm{~cm}^{2}$. A partir do tubo contendo o swab, os mesmos foram agitados por, no mínimo, 30 segundos e a seguir, realizadas diluições na proporção 1:10, 1:100 e 1:1000 e a determinação dos microrganismos foi a mesma já descrita no item anterior. 
Esse procedimento foi realizado durante os meses de maio a outubro, totalizando 30 amostras.

\subsubsection{Análise dos resultados}

Os resultados obtidos nas análises microbiológicas foram submetidos à análise de variância univariada (ANOVA) e as médias comparadas pelo teste de Tukey a 1\% de probabilidade, por meio do programa estatístico XLSTAT v2018.1.

\subsection{Resultados e Discussões}

A Tabela 1 apresenta os resultados da contagem de microrganismos mesófilos na superfície e no interior do gomo nas diferentes etapas do processo: antes do cozimento, após cozimento e após resfriamento.

Tabela 1 - Número de mesófilos (log UFC/g) em gomos de linguiça: antes do cozimento, após cozimento e após resfriamento

\begin{tabular}{|l|c|c|c|c|c|}
\hline \multirow{2}{*}{} & \multirow{2}{*}{$\begin{array}{c}\text { Antes do } \\
\text { Cozimento }\end{array}$} & \multicolumn{2}{|c|}{ Após cozimento } & \multicolumn{2}{c|}{ Após resfriamento } \\
\cline { 3 - 6 } & $\begin{array}{c}\text { Massa } \\
\text { interna }\end{array}$ & Superfície & $\begin{array}{c}\text { Massa } \\
\text { interna }\end{array}$ & Superfície \\
\hline $\begin{array}{l}\text { Média } \\
\text { (log UFC/g) }\end{array}$ & $5,03^{(a)}$ & $1,56^{(b)}$ & $1,59^{(b)}$ & $1,54^{(b)}$ & $1,67^{(b)}$ \\
\hline
\end{tabular}

* letras iguais não há diferença significativa a 99\% de confiança

No programa de cozimento as linguiças devem atingir no centro térmico do gomo temperaturas de, no mínimo, $71,1^{\circ} \mathrm{C}$ (USDA, 1999), limite definido no Plano de APPCC do processo para garantir a eliminação de Salmonella, patógeno identificado como perigo pela equipe de Food Safety do processo de linguiças cozidas. Para o produto em questão (linguiça calabresa defumada) e suas matérias-primas (carne in natura de aves e suínos) a Resolução de Colegiado (RDC) n 12/2001 (BRASIL, 2001), legislação brasileira vigente que apresenta padrões microbiológicos para alimentos destinados ao consumo humano, não estabelece valores de referência para contagens de mesófilos porém, as contagens das bactérias avaliadas são consideradas como importantes indicativos da qualidade higiênico-sanitária do 
produto e do processamento ao qual foi submetido. Ryser \& Schuman (2015) sugerem padrões para contagem total de aeróbios mesófilos em alguns alimentos: carne moída crua de 4 a 7 log UFC/g; carne de frango crua 3 a $4 \log$ UFC/g e condimentos 4 a 5 $\log$ UFC/g.

Além disso, Handley et al. (2018) quantificaram, a partir da rinsagem de carcaças inteiras de frango, a contagem total de aeróbios mesófilos e Enterobacteriaceae, durante o processamento. Os dados microbiológicos de aeróbios mesófilos no pré-resfriamento e pós-resfriamento foram log médios de 3,21 UFC/mL e 0,89 UFC/mL e as contagens de Enterobacteriaceae foram de log médio de 1,95 UFC/mL e 0,35 CFU/mL.

Para satisfazer tanto a segurança microbiológica e qualidade sensorial da carne suína, Kim \& Jang (2018) sugerem que os níveis atuais das diretrizes para a contagem total de aeróbios mesófilos para carne suína deve ser de 1 × $10^{6} \mathrm{UFC} / \mathrm{g}$, apesar do Ministério Koreano - Food and Drug Safety recomendar que a contagem total de aeróbios mesófilos de carne comercializada seja $<1 \times 10^{7} \mathrm{UFC} /$ g, que é uma ordem de grandeza superior aos de outros países ( $\left.1 \times 10^{6} \mathrm{UFC} / \mathrm{g}\right)$. Além disso, alguns estudos relatam que contagem total de aeróbios mesófilos de $1 \times 10^{7} \mathrm{UFC} / \mathrm{g}$ representa o início da deterioração da carne (TANG et al., 2013).

Sukumaran et al. (2018), avaliaram a massa de linguiça bovina antes do cozimento e verificaram que a contagem total de aeróbios mesófilos foi de 2,25 log UFC/g. Após o cozimento e embalagem à vácuo, verificaram que a contagem total de aeróbios mesófilos aumentou de 2,03 log UFC/g no dia 0 para 3,22 log UFC/g após 30 dias de armazenamento ( $p=0,008)$. Após 60, 90 e 120 dias de armazenamento, a contagem total de aeróbios mesófilos foi de 3,11; 3,64 e 3,77 log UFC/g, respectivamente, não havendo diferença significativa dos resultados avaliados aos 30 dias de armazenamento $(p \geq 0,201)$.

Contagem total de aeróbios mesófilos da massa da linguiça antes do cozimento no presente estudo não é menor do que o estudo de Sukumaran et al. (2018), porém está abaixo do nível de deterioração sugerido por Ryser \& Schuman (2015) e Kim \& Jang (2018) para carne crua.

Comparando-se os resultados da contagem de mesófilos aeróbicos após o cozimento, verifica-se que os dados obtidos são semelhantes aos encontrados por Kim et al. (2014), que cozinharam linguiças a uma temperatura de $80^{\circ} \mathrm{C}$ até a 
temperatura do centro do gomo atingir $75^{\circ} \mathrm{C}$, e a contagem total de mesófilos aeróbicos no tempo zero foram de 1,34 log UFC/g.

Li et al. (2019) estudaram a composição da microbiota e a dinâmica populacional de bacon durante o armazenamento refrigerado e não observaram colônias visíveis ( $<2 \log 10 \mathrm{UFC} / \mathrm{g}$ ) no dia 0 . A contagem total de mesófilos e as bactérias ácido láticas cresceram mais rapidamente a partir do dia 15, atingindo o pico no dia 45.

Hajmeer et al. (2011) inocularam Campylobacter jejuni, Escherichia coli 0157:H7, Listeria monocytogenes, Salmonella enterica sorotipo Newport e Yersinia enterocolitica à massa de linguiça defumada. Foram cozidas a 50,55 e $60^{\circ} \mathrm{C}$, apresentando tempos de redução decimais variando de $>10 \mathrm{~min}$ para a maioria dos ensaios a $50^{\circ} \mathrm{C}$ e $<2 \min$ a $60^{\circ} \mathrm{C}$. Tripas de suíno, embutidas com as massas até um diâmetro < $3 \mathrm{~cm}$, comprimento de $10 \mathrm{~cm}$ e peso 75-80 g, foram cozidas e defumadas; os centros das linguiças permaneceram a temperaturas $\geq 60^{\circ} \mathrm{C}$ por $\geq 90 \mathrm{~min}$. Os níveis de contaminantes nas massas (três experiências/patógeno) variaram de 2,3 × $10^{6} \mathrm{a}$ $3,0 \times 10^{10} \mathrm{UFC} / g$ em várias execuções; reduções foram $\geq 5 \log 10$ em todos os casos. E concluíram que, com essas dimensões do gomo (diâmetro e comprimento) e temperatura atingida no centro térmico do gomo têm reduções logarítmicas suficientes para a segurança dos produtos.

Em 2014, Ducic et al., realizaram uma pesquisa para determinar a presença de Salmonella spp., Escherichia coli O157:H7, microbiota natural, pH e aw, em linguiças cruas fermentadas, produzidas a partir de carne suína ou bovina e sem iniciadores de bactérias do ácido láctico. Em recortes de carne, a contagem total de mesófilos variou em torno de 6 log UFC/g e cerca de 5-6 log UFC/g na carne suína e linguiças de carne bovina, respectivamente. A contagem de Enterobacteriaceae (EBC) variou em torno de 3-4 log UFC/g, enquanto as faixas de contagem de $E$. coli (ECC) foram comparativamente menores (por 1-2 registros). Durante a etapa de fermentação-secagem, tanto na carne suína quanto na linguiça, os níveis iniciais de mesófilos (6-7 log UFC/g) aumentaram no processo médio (em aproximadamente 1,52 logs) e permaneceram nesses níveis nos produtos acabados. Durante o mesmo período, as bactérias do ácido láctico (LAB) aumentaram dos níveis iniciais de 5,5-6 log CFU / g para cerca de 7-8 log UFC/g na carne suína e cerca de 8-9 log UFC/g nas linguiças e tornaram-se grupo microbiano predominante. Concluiram que a presença inicial de patógenos veiculados por alimentos na produção de linguiça fermentada 
crua pode ser considerada como um risco potencial de segurança do alimento, uma vez que, é difícil a eliminação total de patógenos, caso as contagens iniciais sejam elevadas. Salmonella spp. e Escherichia coli O157:H7 foram encontrados na massa mas não no produto acabado.

Gonzales-Barron et al. (2015) realizaram um estudo semelhante a Ducic et al. (2014), que tinha como objetivo de esclarecer os fatores de risco e as particularidades da tecnologia de fabricação que explicam a variabilidade entre lotes de linguiças nas contagens de Enterobacteriaceae, Staphylococcus aureus e Listeria monocytogenes no produto, realizaram uma caracterização microbiológica e físicoquímica da linguiça em cinco etapas de produção: matéria-prima (carne suína), misturada dos ingredientes, moagem, defumação e maturação. A fermentação tardia nas linguiças formuladas com nitrito foi parcialmente responsável pelo aumento $(p<$ $0,01)$ de Enterobacteriaceae, $S$. aureus e $L$. monocytogenes da carne crua $(3,21 \mathrm{log}$ UFC/g, 1,30 log UFC/g e 22,2 UFC/g, respectivamente) até ao final da moagem (4,14 $\log \mathrm{UFC} / \mathrm{g}, 2,10 \mathrm{log} \mathrm{UFC} / \mathrm{g}$ e $140 \mathrm{UFC} / \mathrm{g}$, respectivamente) enquanto que o melhor processo de acidificação nas linguiças isentas de nitrito levou a uma menor contagem de $S$. aureus $(2,64 \log \mathrm{UFC} / \mathrm{g})$ e $L$. monocytogenes (10 UFC/g) nos produtos acabados. Na Fábrica II, embora L. monocytogenes tenha entrado na cadeia no ponto de mistura, ela se tornou inativada durante a defumação e a maturação $(<50 \mathrm{UFC} / \mathrm{g})$, apesar da fermentação inicialmente retardada. Concluíram também, que o principal obstáculo que impede o desenvolvimento de $S$. aureus em linguiça é o pH, e outros fatores que contribuem para o seu controle são: dias de maior maturação $(p=0,019)$, baixa concentração inicial de $S$. aureus em carne crua $(p=0,098)$, higienização adequada das tripas $(p=0,094)$ e menor contaminação durante a mistura $(p=0,199)$. No caso de $L$. monocytogenes, pelo menos três obstáculos dificultam seu desenvolvimento em linguiça: baixo aw $(p=0,004)$, baixo $\mathrm{pH}(\mathrm{p}=0,040)$ e nitrito $(\mathrm{p}=$ 0,060 ), e outros fatores que contribuem para o seu controle são: maior período de maturação $(p=0,072)$ e moagem ( $p=0,106)$, menor aw no final da defumação ( $p=$ $0,076)$ e tripas adequadamente lavadas $(p=0,099)$. Com esses resultados, concluíram que há necessidade de padronizar o processo produtivo da linguiça, otimizar o processo inicial de acidificação e reforçar programas adequados de controle de qualidade de ingredientes e boas práticas de higiene, de modo a minimizar a introdução de Enterobacteriaceae e patógenos de organismos externos. 
Mataragas et al. (2015) desenvolveram um modelo preditivo para avaliar os efeitos relativos do $\mathrm{pH}$, atividade de água (aw) e temperatura em $L$. monocytogenes durante a fermentação e maturação de linguiças. Observaram que a temperatura explicava $60 \%$ da variabilidade dos dados, enquanto $\mathrm{pH}$ e aw apenas uma pequena parte porém, somente a temperatura pode não ser suficiente para causar a inativação do patógeno, mas a taxa de inativação é dominada pela temperatura quando o $\mathrm{pH}$ e o aw estão na faixa que impede o crescimento de $L$. monocytogenes.

O cozimento é eficiente, uma vez há diferença significativa $(p<0,01)$ entre as etapas "antes do cozimento" e "após cozimento" além disso, a contagem de mesófilos após a etapa de cozimento é baixa, semelhante aos resultados encontrados por Li et al. (2019) e Kim \& Jang (2018). Apesar das análises terem sido realizadas somente para contagem total de mesófilos aeróbios, os trabalhos descritos acima ajudam a evidenciar a eliminação de patógenos nesse processo de cozimento. Outro ponto a se destacar é que não há recontaminação dos gomos de linguiças após a etapa de cozimento, uma vez que os resultados de swab da superfície dos gomos não varia entre as etapas "após cozimento" e "após resfriamento" $(p<0,01)$.

\subsection{Conclusão}

O cozimento no processo de linguiças cozidas além de ser uma etapa para desenvolver características sensoriais ao produto também é extremamente importante para a redução da carga microbiológica. Porém, para inibir a multiplicação desses microrganismos após essa etapa é importante aliar à outras barreiras que precisam ser pesquisadas. 


\section{Referências}

1. ABNT- Associação Brasileira de Normas Técnicas. NBR ISO 22000:2006 Sistema de Gestão da Segurança de Alimentos: Requisitos para qualquer organização na cadeia produtiva de alimentos. Rio de Janeiro, ABNT, 2004.

2. AOAC Official Methods of Analysis. Microbiological Methods. 990.12. 20th ed. 2016.

3. BRASIL, 2001, RDC n¹2 de 02 de janeiro de 2001 do Ministério da Saúde Anexo I - Padrões Sanitários Microbiológicos para Alimentos.

4. BUNCIC, S.; NYCHAS, G-J.; LEE, M. R. F. et al. Microbial pathogen control in the beef chain: Recent research advances. Meat Science, v. 97, p. 288-297. 2014.

5. DUCIC, M. et. al. General patterns of background microbiota and selected bacterial pathogens during production of fermented sausages in Serbia, Food Control, v. 43, p. 231-237, 2014.

6. GONZALES-BARRON, U.; CADAVEZ, V.; PEREIRA, A. P.; GOMES, A.; ARAÚJO, J.P.; SAAVEDRA M.J.; ESTEVINHO, L.; BUTLER, F.; PIRES, P.; DIAS, T. Relating physicochemical and microbiological safety indicators during processing of linguiça, a Portuguese traditional dry-fermented sausage, Food Research International, v. 78, p.50-61, 2015.

7. HAJMEER, M. N.,et al. Thermal death of bacterial pathogens in linguiça smoking, Food Control, v. 22, p. 668-672. 2011.

8. HANDLEY, J. A.; PARK, S. H.; KIM, S. A.; RICKE, S. C. Microbiome Profiles of Commercial Broilers Through Evisceration and Immersion Chilling During Poultry Slaughter and the Identification of Potential Indicator Microorganisms Frontiers in Microbiology, v. 9. 2018.

9. KIM, H. -W.; CHOI, J. -H.; CHOI, Y. -S.; KIM, H. -Y.; LEE, M. -A.; HWANG, K. -E.; SONG, D. -H.; LEE, J. -W.; KIM, C. -J. Effects of kimchi and smoking on quality characteristics and shelf life of cooked sausages prepared with irradiated pork. Meat Science, v. 96, p. 548-553. 2014.

10.KIM, H., J.; JANG, A. Evaluation of the microbiological status of raw pork meat in Korea: modification of the microbial guideline levels for meat. Food Sci Biotechnol, v. 27(4), p.1219-1225. 2018. 
11. LI, X. et al. Changes in the microbial communities in vacuum-packaged smoked bacon during storage Food Microbiology, v. 77, p. 26-37, 2019.

12. MATARAGAS, M. ; RANTSIOU, K. ; ALESSANDRIA, V. ; COCOLIN, L.

Estimating the non-thermal inactivation of Listeria monocytogenes in fermented sausages relative to temperature, $\mathrm{pH}$ and water activity. Meat Science, v. 100, p. 171-178, 2015.

13.NOOR, S., RADHAKRISHNAN, N. S.; HUSSAIN, K. Sausage formulations and effects of addition of different non-meat ingredients on sausages - a review. International Journal of Livestock Research, v. 6(12), p. 1-19. 2016

14. RYSER, E. T.; SCHUMAN, J. D. Mesophilic Aerobic Plate Count. In: SALFINGER, Y. e TORTORELLO, M. L. Compendium of methods for the microbiological. Examinations of Foods. 5a ed. Washington (DC): American Public Health Association (APHA). p. 95-102. 2015.

15.SANTOS, J.S. Evaluation of microbiological quality of poultry meat sold in the municipality of Aracaju - SE. 2009, 41p. Dissertation (Specialization in Food Sanitary Vigilance) - Rural Federal University of the Semi-Arid, Recife, PE.

16. SILVA, N.; JUNQUEIRA, V. C. A.; SILVEIRA, N. F. A. et al. Manual de Métodos de Análise Microbiológica de Alimentos e Água. In: Contagem total de microrganismos aeróbios mesófilos e psicotróficos em placas. 5. ed. São Paulo: Blucher, 2017. cap. 6, p.73-86.

17.SUKUMARAN, A. T.; HOLTCAMP, A. J.; ENGLISHBEY, A. K. et al. Effect of deboning time on the growth of Samonella, E. coli, aerobic, and lactic acid bacteria during beef sausage processing and storage. Meat Science, v. 139. P. 49-55. 2018.

18. TANG, X.; SUN, X.; WU, V. C. H.; XIE, J.; PAN, Y.; ZHAO, Y.; MALAKAR P. K. Predicting shelf-life of chilled pork sold in China. Food Control, v. 32, p. 334340. 2013.

19.UNITED STATES AND INSPECTION SERVICE, Food Safety and Inspection Service (Updated June 1999) - Appendix A - Compliance Guidelines For Meeting Lethality Performance Standards For Certain Meat And Poultry Products. 


\section{CAPÍTULO 3}




\section{CAPÍTULO 3: ARTIGO 2}

\section{CARACTERIZAÇÃO FíSICO-QUÍMICA DAS LINGUIÇAS COZIDAS}

\subsection{Introdução}

A conservação de alimentos utiliza diferentes técnicas para impedir que os alimentos se deteriorem devido às alterações provocadas por microrganismos, reações químicas enzimáticas e não enzimáticas.

Na busca por alimentos saudáveis, estáveis e que suas características sensoriais sejam preservadas, a indústria de alimentos pode usar uma combinação de métodos de preservação, denominados Tecnologia das Barreiras que, segundo Singh (2016) é uma tecnologia pela qual um parâmetro de preservação pode ser usado em um nível ótimo para obter um letalidade máxima contra microrganismos por uma combinação de dois ou mais desses parâmetros, de modo que o dano aos atributos sensoriais do alimento são mínimos, ou ainda uma preservação inteligente, usando diferentes técnicas (barreiras) para controlar ou eliminar patógenos (RODRIGUEZ-CALLEJA, 2012).

A Tecnologia das Barreiras é aplicada para a preservação suave, mas eficaz de alimentos. Anteriormente, uma combinação de métodos de preservação, era usada empiricamente sem conhecimento dos princípios dominantes. Há cerca de 20 anos, a aplicação inteligente da tecnologia de obstáculos tornou-se mais prevalente, porque os princípios dos principais fatores de preservação para alimentos (por exemplo, temperatura, $\mathrm{pH}$, aw, Eh, flora competitiva), e suas interações, tornaram-se mais conhecidas. Recentemente, a influência dos métodos de conservação de alimentos na fisiologia e o comportamento de microrganismos nos alimentos, isto é, sua homeostase, exaustão metabólica, reações de estresse, entre outros fatores, são levados em conta e assim, surgiu o novo conceito de preservação de alimentos com múltipos alvos (LEISTNER, 2000).

$\mathrm{O}$ pH de um alimento não exerce apenas influência sobre a velocidade de multiplicação dos microrganismos, mas também interfere na qualidade dos alimentos, durante o armazenamento, tratamento térmico, dessecação, ou durante qualquer outro tipo de tratamento, ou seja, é também responsável direto pela deterioração de produtos alimentícios. Cada microrganismo possui um valor ótimo de 
$\mathrm{pH}$, no qual seu crescimento é máximo. As mudanças bruscas no $\mathrm{pH}$ de um alimento podem se refletir na atividade microbiana. Um alimento pode possuir, inicialmente, um $\mathrm{pH}$ que impeça o crescimento bacteriano, mas esse valor pode ser alterado pelo metabolismo de outros microrganismos (mofos e leveduras), permitindo o crescimento bacteriano (FORSYTHE, 2002).

A acidificação é um método de conservação bastante utilizado em alimentos como, por exemplo, em produtos lácteos. Esse método é muito efetivo, uma vez que os principais patógenos de origem alimentar crescem melhor em pHs neutros (FORSYTHE, 2002).

Os microrganismos têm valores de pH mínimo, máximo e ótimo, no qual seu crescimento é máximo. Verifica-se que pH em torno da neutralidade, 7,0 (6,6 $7,5)$ é o mais favorável para a maioria dos microrganismos. Poucos crescem abaixo do $\mathrm{pH} 4,0$. As bactérias tendem a serem mais exigentes na sua relação com o pH do que os bolores e leveduras, e as bactérias patogênicas são as mais exigentes. P.ex: A maioria as carnes tem o pH final de 5,6 ou mais alto, isso torna esses produtos susceptíveis à deterioração por bactérias bem como pelos fungos. Saindo da faixa de pH ótimo de um microrganismo e dirigindo-se em ambas direções, há diminuição do seu crescimento.

A água presente nos alimentos pode ser analisada como atividade de água ou como umidade. A umidade está presente em quase todos os alimentos e tem influência nas propriedades sensoriais e também nas operações envolvidas durante a fabricação de um produto alimentício. O conteúdo da umidade está relacionado também à preservação de alimentos, porque afeta diretamente o crescimento de microrganismos e atividade enzimática, que impactam diretamente na estabilidade $\mathrm{e}$ vida de prateleira de produtos (ISENGARD et al. 2006; ADAM et al. 2009; YILDIRIM et al. 2018). Além disso, o aumento da umidade faz com que o alimento mais suscetível ao crescimento microbiano e pode causar mudanças na textura e na aparência, reduzindo o prazo de validade dos alimentos (MURMU \& MISHRA, 2018), podendo afetar o valor comercial dos produtos, por isso, deve-se fazer da sua determinação uma rotina no controle de qualidade do alimento (ISENGARD, 2008).

Com exceção do Staphylococcus aureus, as bactérias são mais competidoras por água livre do que os fungos. A maioria das bactérias requerem aw mínimo entre 0,88 e 0,91, no entanto, os estafilococos são atípicos, pois são capazes 
de crescer em baixos níveis de atividade de água, com crescimento demonstrado em 0,83, sob condições ideais (FDA, 2012).

Em um ambiente com baixa aw, a água é expulsa rapidamente da célula, causando encolhimento e mudança de forma celular e alterações nas atividades metabólicas (PLEMENITAŠ et al., 2014).

\subsection{Objetivo}

Avaliar a quantidade de gordura, proteínas, $\mathrm{pH}$, umidade e atividade de água de linguiças cozidas e defumadas produzidas entre os meses de maio a outubro de 2018, por meio das cartas de controle geradas no período;

\subsection{Materiais e Métodos}

\subsubsection{Avaliações físico-químicas}

As amostras foram coletadas diretamente da linha de processamento, logo após sua produção e levadas ao laboratório interno da própria unidade industrial, localizado no interior de Minas Gerias. A seguir foram preparadas sem a retirada do invólucro (tripa), de forma que no mínimo 5 gomos foram moídos em discos de $5 \mathrm{~mm}$ de diâmetro por 2 ou 3 vezes, até que se obtivesse uma massa homogênea.

Os parâmetros físico-químicos foram determinados de acordo com a metodologia descrita pelo Ministério da Agricultura Pecuária e abastecimento (MAPA), baseada em normas da ISO (BRASIL, 2017), de forma que a determinação do teor de umidade foi realizada de acordo com a norma ISO 1442 e o resultado reportado em porcentagem, a quantidade de gordura foi realizada por hidrólise ácida, conforme norma ISO 1443, e o resultado reportado também em porcentagem, a atividade de água (aw) foi realizada utilizando-se analisador automático da marca Aqualab Series 4TE, o teor de proteínas foi realizado pelo método de Kjeldahle a determinação do $\mathrm{pH}$ foi realizada utilizando-se um medidor de $\mathrm{pH}$ de bancada FiveEasy Plus, Metler Toledo, Modelo FEP20-ACT-KIT, 100 - 240V, 50/60 Hz.

\subsubsection{Análise dos resultados}

Todos os resultados obtidos para os parâmetros físico-químicos, foram plotados em cartas de controle, geradas pelo Excelß 2016. Dos resultados, foram avaliados mais de 800 dados plotados de cada parâmetro. 
Além disso, foi realizada análise de correlação de Pearson entre os dados de umidade x gordura e umidade x proteína.

\subsection{Resultados e Discussões}

Dos dados obtidos pelas cartas de controle foi possível determinar a média, mediana e desvio padrão dos parâmetros físico-químicos para as amostras de linguiças produzidas entre os meses de maio a outubro de 2018 (Tabela 1).

Tabela 1 - Parâmetros físico-químicos das amostras de linguiças cozidas e defumadas produzidas entre os meses de maio a outubro de 2018.

\begin{tabular}{lccccc}
\hline & \% Proteína & \% Gordura & \% Umidade & aw & pH \\
\hline Média & 16,58 & 26,12 & 50,51 & 0,938 & 6,33 \\
\hline Mediana & 16,52 & 26,17 & 50,45 & 0,939 & 6,34 \\
\hline $\begin{array}{l}\text { Desvio } \\
\text { Padrão }\end{array}$ & 0,92 & 2,52 & 1,94 & 0,006 & 0,11 \\
\hline
\end{tabular}

As cartas de controle são apresentadas nas Figuras 1, 2, 3, 4 e 5 e mostram o comportamento dos resultados em porcentagem de Proteína, Gordura, Umidade, Atividade de Água e pH, respectivamente, ao longo dos meses avaliados.

Figura 1: - Carta de controle gerada pela quantificação de Proteínas presentes em linguiças cozidas e defumadas, produzidas entre os meses de maio a outubro de 2018. 


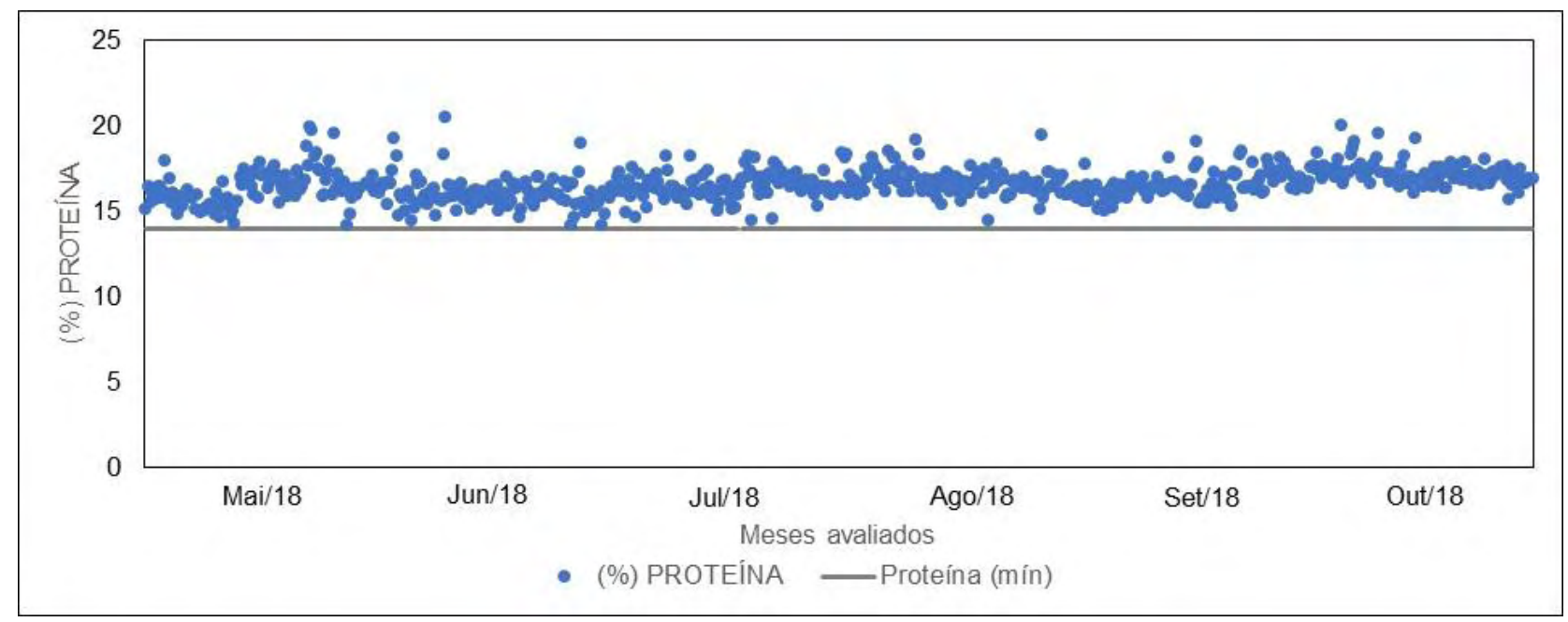

Segundo o RTIQ da linguiça o percentual mínimo de proteína para linguiças cozidas é de 14\% (BRASIL, 2000). Pela Tabela 1 e Figura 1 observa-se que há o atendimento à legislação.

Figura 2: - Carta de controle gerada pela quantificação de Gordura presente em linguiças cozidas e defumadas, produzidas entre os meses de maio a outubro de 2018.

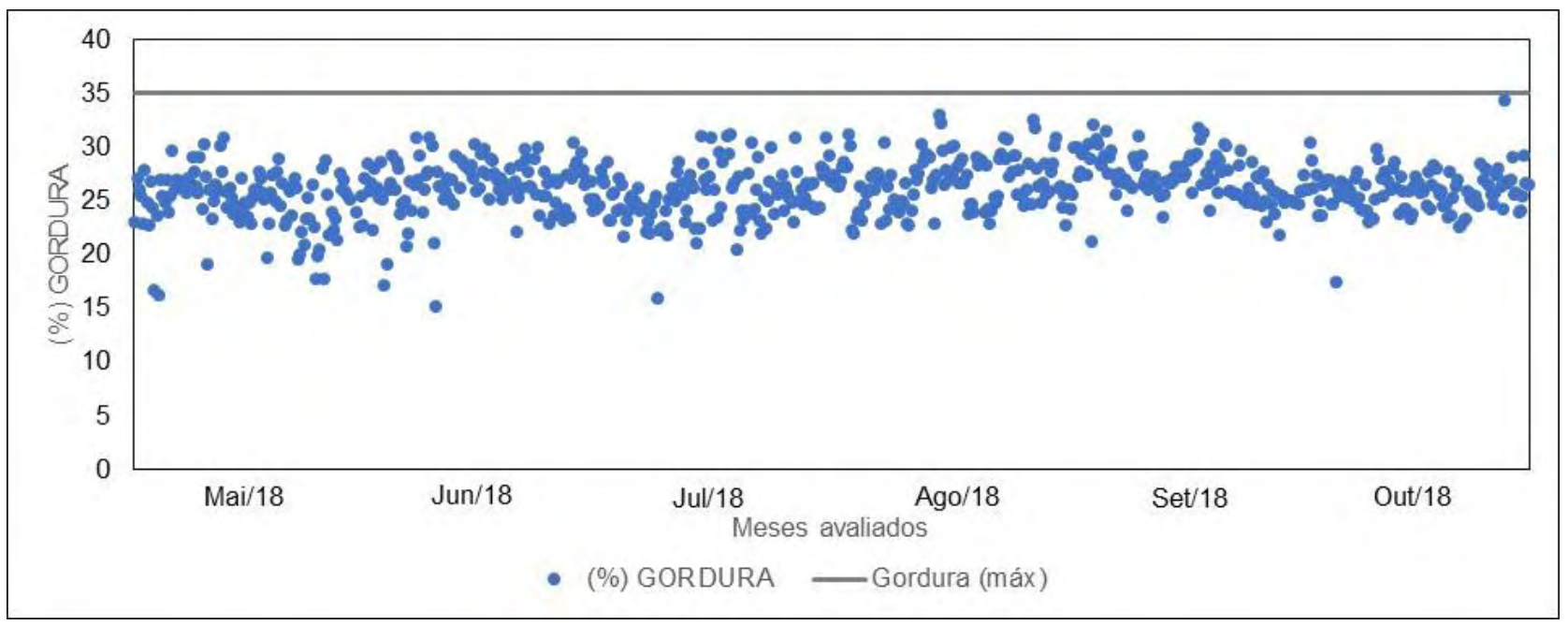

Para atendimento ao RTIQ o percentual de gorduras nas linguiças cozidas não pode ultrapassar 35\% (BRASIL, 2000). A média das amostras ficou bem abaixo do estabelecido $26,35 \%$ (Tabela 1 e Figura 2).

Lorenzo \& Franco (2012), estudaram o efeito do teor de gordura sobre as características químicas relacionadas com o processo de cura a seco $(\mathrm{pH}$, umidade 
e atividade de água), propriedades de cor, textura, alterações de ácidos graxos livres e composições de aminoácidos durante o processamento de linguiças curadas. Concluiram que o nível de gordura afetou a cor e textura ao final do processo, mostrando linguiça com o teor superior de gordura, apresentaram maiores valores de luminosidade e menor dureza. Neste estudo não detectaram diferenças significativas $(p>0,05)$ entre os lotes nas contagens totais de mesófilos, bactérias lácticas e Microccaceae durante o processo porém, o teor de gordura dos testes era de $5 \%, 10 \%$ e 20\%; baixo teor de gordura (LF), gordura média (MF) e alto teor de gordura (HF), respectivamente.

Figura 3: - Carta de controle gerada pela determinação da Umidade em linguiças cozidas e defumadas, produzidas entre os meses de maio a outubro de 2018.

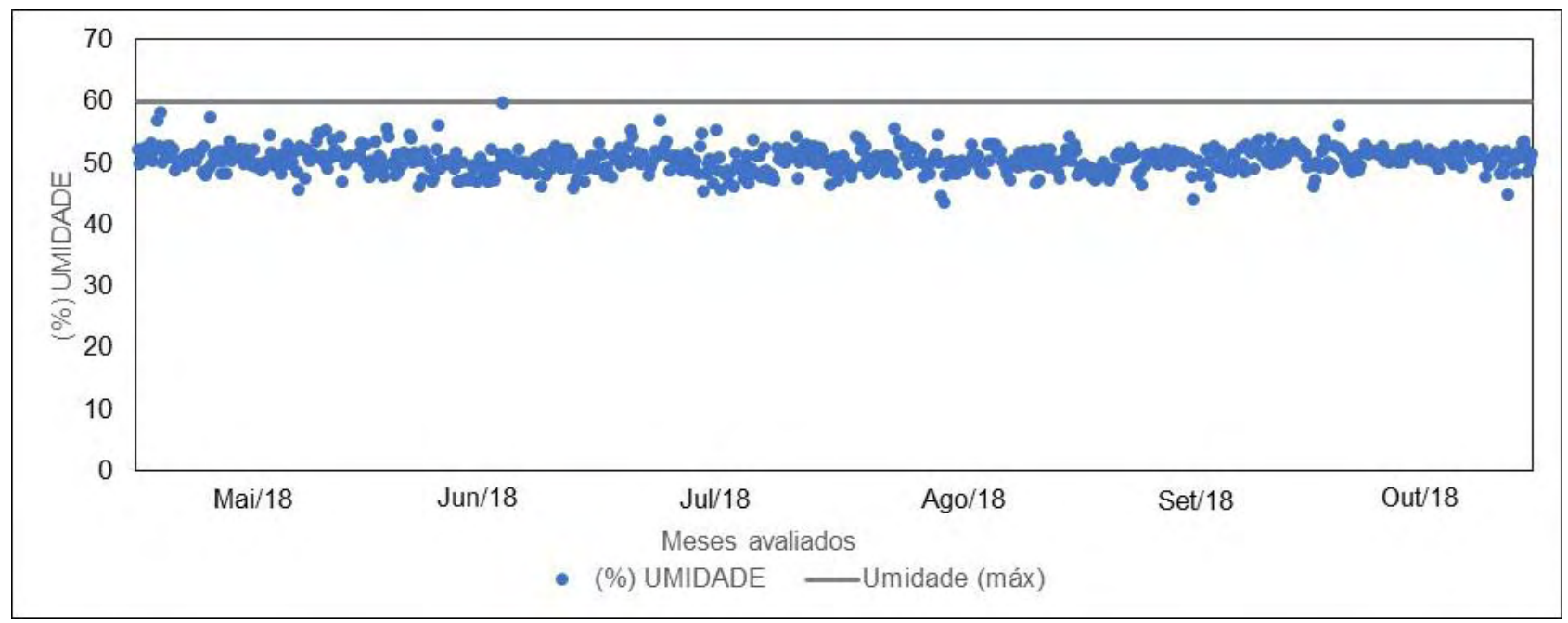

Segundo o Regulamento Técnico de Identidade e Qualidade (RTIQ), o percentual de umidade de linguiças cozidas deve ser de, no máximo, 60\%. Pela Tabela 1 e Figura 3, observa-se valores abaixo do estipulado pelo regulamento.

Segundo Toldrá (2002), os percentuais de proteína e água diminuem quando a gordura aumenta.

Avaliando os dados obtidos nesse trabalho na empresa "A", observa-se uma correlação negativa $(r=-0,76)$ entre \% de Umidade e \% de Gordura porém, não há uma correlação forte entre \% Umidade e \% Proteína $(r=-0,36)$.

Yim et al. (2016) observou que os teores de umidade, proteína e cinzas foram inversamente proporcionais ao teor de gordura durante a maturação e a 
secagem de linguiças. Quanto menor o teor de gordura adicionado, maior o teor de umidade, proteína e cinzas e menor teor de gordura foram observados. O teor de umidade variou de $51,48 \%$ a $63,91 \%$ no dia 0 e de $17,69 \%$ a $25,03 \%$ no $21^{\circ}$ dia. No dia 0 , o teor de umidade foi o maior $(p<0,05)$ nas amostras com gordura reduzida. Trabalhos semelhantes foram relatados por Muguerza et al. (2002) e Olivares et al. (2010), que verificaram que linguiças com redução de gordura apresentaram menor teor de gordura e maior teor de umidade, proteína e cinzas.

Figura 4: - Carta de controle gerada pela determinação da Atividade de Água em linguiças cozidas e defumadas, produzidas entre os meses de maio a outubro de 2018.

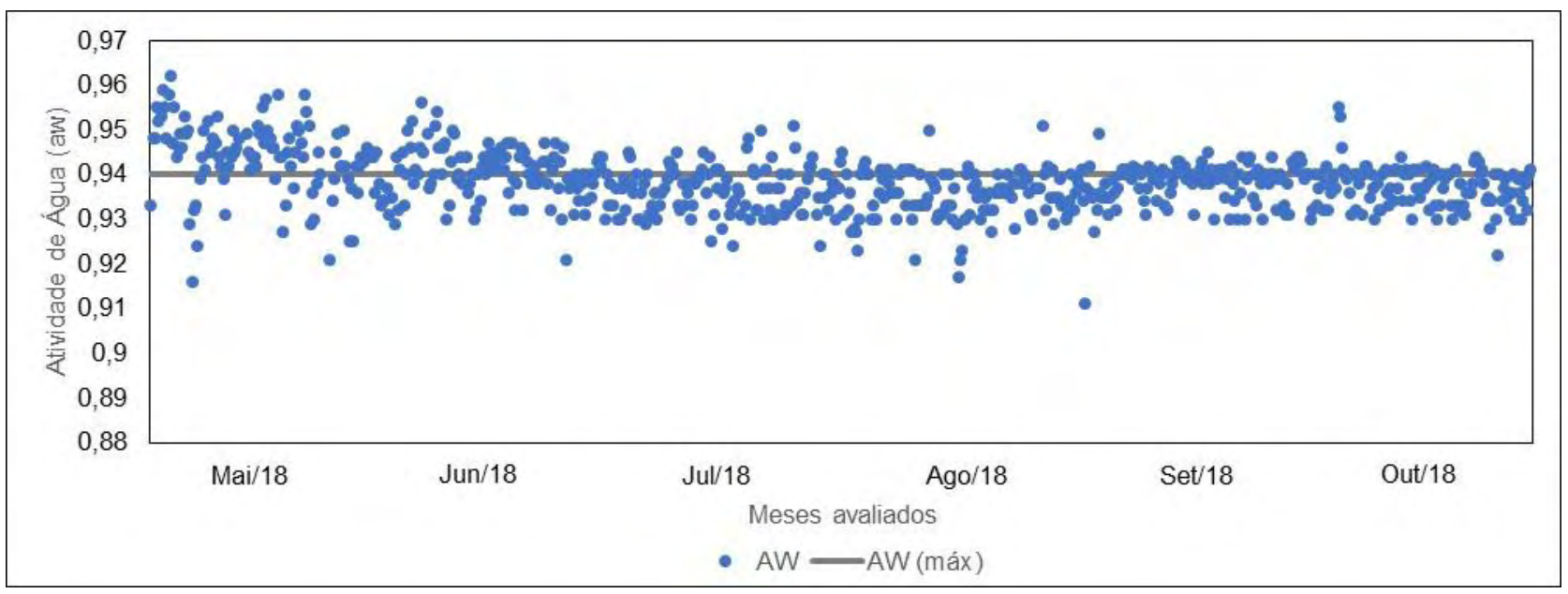

Para atividade de água não há nenhuma legislação que determine o seu limite. Internamente, pensando em inibir o desenvolvimento microbiológico, a empresa definiu 0,94 como valor máximo para este produto.

Figura 5: - Carta de controle gerada pela determinação do pH em linguiças cozidas e defumadas, produzidas entre os meses de maio a outubro de 2018. 


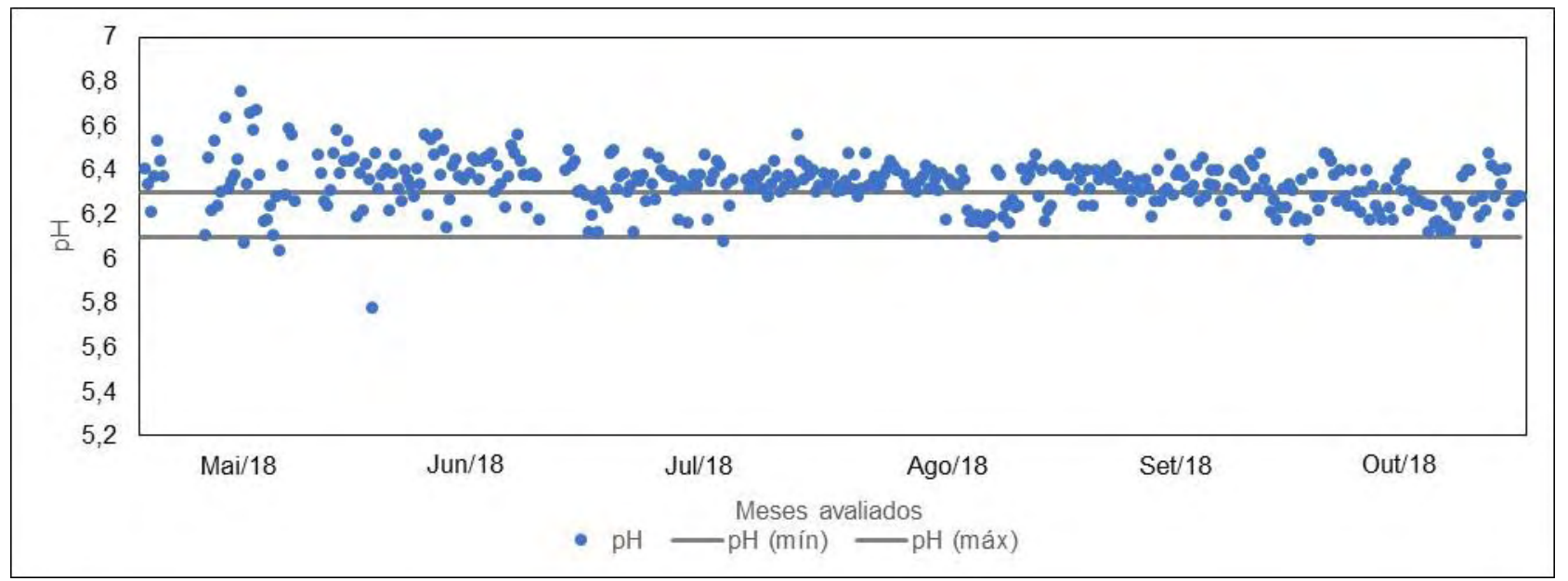

Assim como para a atividade de água, também não há nenhuma legislação que determine os valores para pH porém, internamente definiu-se um valor entre 6,1 a 6,3 .

García-Fontán et al. (2007), realizaram um estudo para a caracterização microbiológica do Botillo, uma tradicional linguiça suína espanhola. Perceberam que houve um desaparecimento progressivo das Enterobacteriaceae durante a maturação das linguiças e que estava relacionado diretamente à acidificação, diminuição do pH em consequência da fermentação que ocorre neste tipo de produto $(\mathrm{pH}=5,54)$, e ao processo de desidratação: aw=0,956 e umidade=50,57, mostrando-se incompatíveis com o sobrevivência deste grupo de microrganismos.

Gonzales-Barron, et al. (2015), relacionando indicadores físico-químicos e microbiológicos durante processamento de uma linguiça tradicional portuguesa, de fermentação a seco, chegaram a resultados ainda menores que o estudo de GarcíaFontán et al. (2007), com valores de $\mathrm{pH}=5,43$; $\mathrm{aw}=0,92$ e umidade=46, contribuindo para a proteção do produto contra microorganismos indesejáveis.

Mataragas et. al (2015) realizaram um estudo para avaliar se os patógenos de origem alimentar Listeria monocytogenes e Salmonella enterica poderiam sobreviver durante a produção de duas salsichas italianas fermentadas. Ao final do trabalho, perceberam que, embora a diminuição do $\mathrm{pH}$ tenha sido rápida durante as primeiras 48 horas de fermentação, a temperatura aplicada (abaixo de $20^{\circ} \mathrm{C}$ ), a desidratação lenta das salsichas e as pequenas mudança de aw não contribuíram para inativação rápida dos microrganismos patogênicos ou seja, ambos os patógenos sobreviveram relativamente bem. 
Semelhante ao presente estudo, outros autores relataram resultados parecidos: Dias et al. (2013) avaliou o pH e aw de linguiças frescas de carne de suína e, no dia 0 , observaram que o $\mathrm{pH}$ das amostras variavam de 5,60 a 6,97 e aw era próximo de 0,97 e, concluiu que com esses parâmetros de pH e aw, as linguiças carne suína eram altamente perecíveis e serviam como substratos para vários microrganismos deteriorantes e patogênicos devido a seu elevado teor de água, abundância de nutrientes essenciais e pH favorável ao desenvolvimento microbiano. Sukumaran et al. (2018), observou que, logo após o cozimento, o pH da linguiça cozida era de 6,0, também observou que esse valor de $\mathrm{pH}$ favoreceu 0 desenvolvimento microbiano, uma vez que, a contagem total de aeróbios mesófilos aumentou de 2,03 log UFC/g no dia 0 para 3,22 log UFC/g após 30 dias.

Diante dos estudos descritos acima, fica evidente a importância da redução dos valores de $\mathrm{pH}$ e aw para inibição do desenvolvimento microbiano.

Para efeitos de comparação com a linguiça cozida e defumada produzida ne empresa, a Tabela 2 apresenta dados de $\mathrm{pH}$, umidade e aw em linguiça cozida, linguiças fermentadas e salame fabricado no Brasil.

Tabela 2 - Comparação dos dados de pH, umidade e aw da linguiça cozida e defumada produzida pela empresa "A", linguiças fermentadas e salame fabricado no Brasil

$\begin{array}{cccc}\text { Linguiça } & \text { Botillo, } & \text { Linguiça, } & \text { Salame } \\ \text { cozida e } & \text { produto } & \text { origem } & \text { fabricado } \\ \text { defumada } & \text { espanhol } & \text { portuguesa } & \text { no Brasil }\end{array}$

(a)

(b)

(c)

(d)

\begin{tabular}{lllll}
\hline pH & 6,33 & 5,54 & 5,43 & $5,0^{*}$ \\
\hline Umidade (\%) & 50,51 & 50,57 & 46 & 40 \\
\hline Aw & 0,938 & 0,956 & 0,923 & 0,92 \\
\hline
\end{tabular}
(a) Produto deste estudo
(b) García-Fontán, M et. al. 2007
(c) Gonzales-Barron, U. et. al. 2015
(d) Regulamento Técnico de Identidade e Qualidade do Salame, Brasil (2000)
* Valor com base nos salames fabricados pela empresa estudada

Pelas características físico-químicas a linguiça protuguesa se assemelha muito ao salame produzido no Brasil. A linguiça Botillo, possui \% de 
umidade semelhante à linguiça cozida porém, com valores de $\mathrm{pH}$ bem menores, isso se deve ao fato de que o primeiro é um produto fermentado e o segundo não é fermentado, passa pelos processos de cozimento e defumação.

Comparando esses dados não é possível afirmar que os parâmetros físico-químicos da linguiça cozida, produzida no Brasil, são capazes de auxiliar na inibição do desenvolvimento microbiano após a etapa de cozimento.

\subsection{Conclusão}

Para os produtos fermentados, a redução do $\mathrm{pH}$, a secagem pela evaporação da água e a redução da atividade de água, possuem um efeito sinérgico que contribuem diretamente para a inibição do crescimento microbiano. Para as linguiças cozidas, como não há uma redução do $\mathrm{pH}$, somente baixa de aw e baixa umidade não são sufiecientes para inibir o crescimento microbiano. Neste caso, é necessário investigar barreiras adicionais para alcançar este objetivo. 


\section{Referências}

1. ADAM, M.; DOBIAS, P.; BAJEROVA, P.; VENTURA, K. Comparison of various methods for determination of water in white yoghurts. Food Chem. v. 115, p. 1069-1073. 2009.

2. BRASIL, 2017, Ministério da Agricultura, Pecuária e Abastecimento. Manual de métodos oficiais para análise de alimentos de origem animal /Ministério da Agricultura, Pecuária e Abastecimento. Secretaria de Defesa Agropecuária. Brasília: MAPA, .140 p. ISBN 978-85-7991-111-8

3. BRASIL, 2000, Ministérios da Agricultura, Pecuária e Abastecimento, Instrução Normativa $n^{\circ} 4$ de 31 de março de 2000 da SDA e DIPOA - Anexo III Regulamento Técnico para Fixação de Identidade e Qualidade de Linguiça.

4. DIAS, F. S.; RAMOS, C. L.; SCHWAN, R. F. Characterization of spoilage bacteria in pork sausage by PCR-DGGE analysis. Food Science and Technology, v. 33(3), p.468-474, 2013.

5. FORSYTHE, S. J. Microbiologia da Segurança Alimentar. Porto Alegre: Artmed, 2002.

6. GARCÍA-FONTÁN, M. C., LORENZO, J. M., MARTíNEZ, S., Franco, I., CARBALLO, J. Microbiological characteristics of Botillo, a Spanish traditional pork sausage. LWT-Food Science and Technology, v. 40, p. 1610-162. 2007.

7. GONZALES-BARRON, U. et. al. Relating physicochemical and microbiological safety indicators during processing of linguiça, a Portuguese traditional dryfermented sausage. Food Research International, v. 78, p. 50-61, 2015.

8. INTERNATIONAL ORGANIZATION FOR STANDARDIZATION - ISO. International Standard - Método ISO 1443, 1 ed., Meat and meat products Determination of total fat content. 1973.

9. ISENGARD, H.D.; KLING, R.; REH, C.T. Proposal of a new reference method to determine the water content of dried dairy products. Food Chem. v. 96, p. 418422. 2006.

10. ISENGARD, H.-D. Water determination - scientific and economic dimensions. Food Chem. v. 106, 1393-1398. 2008. 
11. LEISTNER, L. Basic aspects of food preservation by hurdle technology. Int. J. Food Microbiol, v. 55, p. 181-186. 2000.

12. LORENZO, J. M. ; FRANCO, D. Fat effect on physico chemical, microbial and textural changes through the manufactured of dry-cured foal sausage Lipolysis, proteolysis and sensory properties. Meat Science, v. 92, p. 704-714, 2012.

13. MATARAGAS, M. ; RANTSIOU, K. ; ALESSANDRIA, V. ; COCOLIN, L.

Estimating the non-thermal inactivation of Listeria monocytogenes in fermented sausages relative to temperature, $\mathrm{pH}$ and water activity. Meat Science, v. 100, p. 171-178, 2015.

14. MATARAGAS, M. et al. Risk-based control of food borne pathogens Listeria monocytogenes and Salmonella enterica in the Italian fermented sausages Cacciatore and Felino. Meat Science, v. 103, p. 39-45, 2015.

15.MUGUERZA, E.; FISTA, G.; ANSORENA, D.; ASTIASARAN, I.; BLOUKAS, J. G. Effect of fat level and partial replacement of pork backfat with olive oil on processing and quality characteristics of fermented sausages. Meat Sci., v. 61, p. 397-404, 2002.

16. MURMU, S. B.; MISHRA, H. N. Selection of the best active modified atmosphere packaging with ethylene and moisture scavengers to maintain quality of guava during low-temperature storage. Food Chem, v. 253, p. 55-62. 2018.

17. OliVARES, A.; NAVARRO, J. L; SALVADOR, A.; FLORES, M. Sensory acceptability of slow fermented sausages based on fat content and ripening time. Meat Sci., v. 86, p. 251-257, 2010.

18. PLEMENITAŠ, A.; LENASSI, M.; KONTE, T.; KEJŽAR, A.; ZAJC, J.; GOSTINČAR, C.; GUNDE-CIMERMAN, N. Adaptation to high salt concentrations in halotolerant/halophilic fungi: A molecular perspective. Frontiers in Microbiology, v. 5. 2014.

19.RODRIGUEZ-CALLEJA, J. M.; CRUZ-ROMERO, M. C.; O'SULLIVAN, M. G.; GARCIA-LOPEZ, M. L.; KERRY, J. P. High-pressure-based hurdle strategy to extend the shelf-life of fresh chicken breast fillets. Food Control, v.25, p. 516524.2012 . 
20.SINGH, S.; SHALINI R. Effect of Hurdle Technology in Food Preservation: A Review, Critical Reviews in Food Science and Nutrition, v. 56, p. 641-649. 2016.

21.SUKUMARAN, A. T.; HOLTCAMP, A. J.; ENGLISHBEY, A. K. et al. Effect of deboning time on the growth of Samonella, E. coli, aerobic, and lactic acid bacteria during beef sausage processing and storage. Meat Science, v. 139. P. 49-55. 2018.

22. TOLDRÁ, F., Dry-cured Meat Products. Food \& Nutrition Press. 2002.

23. YILDIRIM, S.; RÖCKER, B.; PETTERSEN, M. K.; NILSEN-NYGAARD, J.; AYHAN, Z.; RUTKAITE, R. et al. Active packaging applications for food. Compr Rev Food Sci Food Saf, v. 17(1). p. 165-199. 2018.

24. YIM, D., G.; JANG, K., H.; CHUNG, K., Y. Effect of fat level and the Ripening Time on Quality Traits of Fermented Sausages. Asian Australas. J. Anim. Sci., v.29, p. 119-125, 2016. 


\section{CAPÍTULO 4}




\section{CAPÍTULO 4: ARTIGO 3}

\section{ESTUDO DE SHELF-LIFE DAS LINGUIÇAS COZIDAS}

\subsection{Introdução}

O processo de preservar embutidos de carne, carnes salgadas e picadas, aromatizadas com especiarias, em invólucros de animais, remonta a milhares de anos, aos antigos gregos e romanos. A palavra "salsicha" é derivada da palavra latina "salsus", que significa salgado, ou preservado por salga. Salsichas e linguiças, desde então, evoluíram para uma grande variedade de sabores, texturas e formas resultantes de variações nos ingredientes e processos de fabricação. Nos Estados Unidos, a expansão da indústria de embalagem de carne ocorreu durante a Guerra Civil, juntamente com o desenvolvimento da refrigeração para uso em vagões ferroviários e instalações de abate e incentivou os processadores de carne a criar produtos que pudessem utilizar cortes de carne mais baratos e perecíveis, juntamente com retalhos e miúdos. Além disso, pessoas de várias nacionalidades e grupos étnicos imigraram para os Estados Unidos, trazendo consigo receitas tradicionais e habilidades de fabricação para criar uma ampla variedade de tipos de salsichas e linguiças e uma diversidade de ingredientes de carne crua é utilizada no processo de produção, cada ingrediente contribui com uma propriedade específica para a formulação final (NOOR et al., 2016).

As linguiças e salsichas são altamente perecíveis e servem como substratos para vários microrganismos deteriorantes e patogênicos devido a seu elevado teor de água e abundância de nutrientes.

A deterioração pode ser definida como qualquer alteração num alimento que o torna inaceitável para o consumidor do ponto de vista sensorial. A deterioração microbiana é de longe a causa mais comum de deterioração e pode se manifestar como visível crescimento (lodo, colônias), como alterações na textura (degradação polímeros) ou como sabores desagradáveis (GRAM et al., 2002). No caso de carne e produtos cárneos, a deterioração microbiana leva ao desenvolvimento de aromas anormais, rancidez oxidativa, descoloração, produção de gás e, muitas vezes formação de limo (DIAS et al., 2013). 
Bactérias ácido láctico (LAB) constituem um grupo heterogêneo que tem sido amplamente associado à deterioração de carne fresca e produtos de carne cozidos. Elas representam um grupo controverso de espécies microbianas que contribuem para deterioração através da geração de metabolitos ofensivos e subsequente desclassificação organoléptica de carne ou servem como agentes bioprotetores com cepas de certas espécies causando imperceptível ou nenhuma alteração (VASILEIOS et al., 2015; POTHAKOS et al., 2015). Originalmente esse grupo incluia quatro gêneros: Lactobacillus, Leuconostoc, Pediococcus e Streptococcus. Gradativamente, esses gêneros foram subdivididos no novos gêneros Carnobacterium, Enterococcus, Fructobacillus, Lactococcus, Oenococcus, Tetragenococcus, Vagococcus e Weissella (SILVA et al., 2017).

Todas são Gram positivas, não esporogênicas, anaeróbias facultativas, catalase e oxidase negativas. O metabolismo de carboidratos pode ser homofermentativo, resultando primordialmente em ácido láctico, ou heterofermentativo, resultando em ácido lático, $\mathrm{CO}_{2}$ e outros produtos de fermentação (SILVA et al., 2017).

\subsection{Objetivos}

Verificar a estabilidade das características de qualidade sensoriais do produto ao longo do shelf-life e avaliar se os parâmetros de recusa estão associados às características de deterioração pelas bactérias ácido láticas.

\subsection{Materiais e Métodos}

Os ensaios ao longo do teste foram relacionados com as características sensoriais do produto, que poderiam se alterar em decorrência do tempo de estocagem. Utilizou-se o critério da Especificação Sensorial, documento interno pertencente a empresa " $A$ " que descreve os atributos dos produtos: aparência, odor, sabor e textura.

Abaixo estão listados os atributos sensoriais avaliados: aparência da embalagem fechada, aparência externa dos gomos após abertura da embalagem, aparência interna da fatia, odor antes do preparo, sabor e textura. 
Tabela 1 - Atributos avaliados durante o estudo de shelf life das linguiças cozidas defumadas.

\begin{tabular}{|c|c|c|c|c|c|}
\hline $\begin{array}{c}\text { Aparência } \\
\text { embalagem } \\
\text { fechada }\end{array}$ & $\begin{array}{c}\text { Aparência } \\
\text { externa dos } \\
\text { gomos após } \\
\text { abertura da } \\
\text { embalagem: }\end{array}$ & $\begin{array}{c}\text { Aparência } \\
\text { interna da } \\
\text { fatia }\end{array}$ & $\begin{array}{c}\text { Odor } \\
\text { antes do } \\
\text { preparo }\end{array}$ & Sabor & Textura \\
\hline $\begin{array}{l}\text { - Cor } \\
\text { acastanhada } \\
\text { - Homogeneida } \\
\text { de de cor } \\
\text { entre os } \\
\text { gomos. } \\
\text { - Vácuo e } \\
\text { - Defeitos (por } \\
\text { exemplo, } \\
\text { presença de } \\
\text { líquido no } \\
\text { pacote, ou } \\
\text { líquido turvo) }\end{array}$ & $\begin{array}{l}\text { - Gomos } \\
\text { íntegros } \\
\text { - Brilho } \\
\text { - Rugas no } \\
\text { gomo } \\
\text { - Defeitos (por } \\
\text { exemplo, } \\
\text { presença de } \\
\text { mela, marcas } \\
\text { de contato, } \\
\text { fuligem, } \\
\text { gomos } \\
\text { tortos/retorci } \\
\text { dos, massa } \\
\text { aderida ao } \\
\text { gomo) }\end{array}$ & $\begin{array}{l}\text { - Homogeneida } \\
\text { de de cor da } \\
\text { massa } \\
\text { - Homogeneida } \\
\text { de de cor da } \\
\text { carne } \\
\text { - Cor interna } \\
\text { - Aderência dos } \\
\text { cubos de } \\
\text { gordura } \\
\text { - Integridade da } \\
\text { gordura } \\
\text { - Integridade da } \\
\text { fatia no corte } \\
\text { - Quantidade de } \\
\text { carne } \\
\text { - Quantidade de } \\
\text { gordura } \\
\text { - Tamanho dos } \\
\text { pedaços de } \\
\text { carne } \\
\text { - Defeitos (por } \\
\text { exemplo, } \\
\text { bolhas de ar, } \\
\text { manchas, } \\
\text { grumos, corpos } \\
\text { estranhos) }\end{array}$ & $\begin{array}{l}\text { - Defuma } \\
\text { do } \\
\text { - Temper } \\
\text { o } \\
\text { - Defeitos } \\
\text { (por } \\
\text { exemplo } \\
\text {, ranço, } \\
\text { ácido, } \\
\text { pútrido) }\end{array}$ & $\begin{array}{l}\text { - Defumad } \\
\text { o } \\
\text { - Carne } \\
\text { - Tempero } \\
\text { - Gosto } \\
\text { salgado } \\
\text { - Picância } \\
\text { - Defeitos } \\
\text { (por } \\
\text { exemplo, } \\
\text { ranço, } \\
\text { ácido) }\end{array}$ & $\begin{array}{l}\text { - Maciez } \\
\text { - Textura de } \\
\text { carne } \\
\text { - Suculência } \\
\text { - Defeitos } \\
\text { (sensação } \\
\text { gordurosa, } \\
\text { "arenosida } \\
\text { de") }\end{array}$ \\
\hline
\end{tabular}

Durante os meses de janeiro a outubro de 2018, foram coletados produtos acabados diretamente da linha de produção, quantidade de pacotes suficientes para realizar o estudo conforme frequência definida abaixo, totalizando 17 estudos nos dez meses avaliados. 
Os pacotes foram armazenados a temperatura ambiente, uma vez que é a forma como são comercializadas, no laboratório de análise sensorial da própria unidade produtora, localizado no interior de Minas Gerais.

As amostras foram avaliadas conforme frequência definida abaixo:

- 1‥ Avaliação: tempo zero

- 2 ${ }^{\mathrm{a}}$. Avaliação: 45 dias, metade do tempo decorrido do shelf-life estabelecido.

- 3a. Avaliação: 67 dias, 3/4 do shelf-life estabelecido.

- 4a . Avaliação: 75 dias

- 5a. Avaliação: 90 dias, tempo em que o produto atinge o shelflife estabelecido.

A avaliação sensorial é realizada pela analista do Laboratório Sensorial da própria unidade produtora, esta pessoa possui uma grande experiência em avaliação sensorial, de forma que tem uma grande capacidade avaliação de uma diversidade de produtos.

A performance analítica dos analistas sensoriais é avaliada através da participação em testes Inter e Intralaboratoriais, baseado na ISO/IEC 17043/2017. O estudo visa balizar a calibração dos analistas frente aos padrões sensoriais estabelecidos pela companhia, assegurando a confiabilidade dos resultados.

Para padronização das avaliações utilizou-se classificação descrita na Tabela 2, a qual mostra a escala utilizada para a classificação das amostras durante a avaliação sensorial, utilizada pela empresa "A", de acordo com metodologias sensoriais (DUTCOSKY, 2015).

O ponto que determina a data da durabilidade do produto é a data da avaliação anterior a avaliação com notas de recusa (notas +/- 3).

As amostras foram preparadas cortando-se os gomos de linguiças em rodelas com espessura das fatias entre 3 a $5 \mathrm{~mm}$. Após, foram fritas em frigideira de material antiaderente, sem tampa e sem adição de óleo, até que ficassem douradas (2 a 3 minutos), mexendo sempre, tomando o cuidado para que as fatias fritassem em ambos os lados. Ao final, as fatias foram retiradas da frigideira e iniciava-se a 
avaliação. Vale ressaltar que a temperatura do produto pode interferir no resultado da análise logo, a análise era realizada imediatamente após o preparo.

Tabela 2 - Escala utilizada na avaliação de atributos sensoriais utilizada pela empresa "A", adaptada de Dutcosky, 2015.

\begin{tabular}{|c|c|}
\hline Índice & Descrição \\
\hline 3 & $\begin{array}{l}\text { Característica muito mais intensa ou presente quando comparada com a } \\
\text { descrição do padrão }\end{array}$ \\
\hline 2 & $\begin{array}{l}\text { Característica moderadamente mais intensa ou presente quando comparada } \\
\text { com a descrição do padrão }\end{array}$ \\
\hline 1 & $\begin{array}{l}\text { Característica ligeiramente mais intensa ou presente quando comparada com } \\
\text { a descrição do padrão }\end{array}$ \\
\hline 0 & Característica de acordo com a descrição do padrão \\
\hline-1 & $\begin{array}{l}\text { Característica ligeiramente menos intensa ou presente quando comparada } \\
\text { com a descrição do padrão }\end{array}$ \\
\hline-2 & $\begin{array}{l}\text { Característica moderadamente menos intensa ou presente quando comparada } \\
\text { com a descrição do padrão }\end{array}$ \\
\hline-3 & $\begin{array}{l}\text { Característica muito menos intensa ou presente quando comparada com a } \\
\text { descrição do padrão }\end{array}$ \\
\hline
\end{tabular}

\subsection{Resultados e Discussões}

A Figura 1 mostra os resultados da avaliação do shelf life de lotes de linguiças cozidas e defumadas produzidas entre os meses de janeiro a outubro de 2018.

Dos 17 estudos realizados, 17\% não chegaram aos 45 dias de shelf-life, $23 \%$ atenderam 45 dias, $23 \%$ atenderam 60 dias, $12 \%$ atenderam 75 dias e somente $23 \%$ atingiu o shelf-life estabelecido, que são de 90 dias.

Os principais motivos para encerramento dos estudos foram por notas de recusa $(+3)$ para os atributos odor ácido e aparência, destacando-se a presença de líquido turvo e mela nos pacotes de linguiças cozidas e em alguns casos, embalagens estufadas, que são característicos de presença de bactérias lácticas. 
Li et. al. (2019) estudaram a composição da microbiota e a dinâmica populacional de bacon durante 0 armazenamento refrigerado, concluiu que a composição microbiana mudou muito com a prolongação do tempo de armazenamento. A diversidade da microbiota foi abundante na fase inicial e, em seguida, houve uma diminuição contínua. Bactérias lácticas, principalmente Leuconoc spp e Lactobacillus spp dominaram a população microbiana após sete dias de armazenamento.

Figura 1 - Gráfico de resultados do shelf-life de linguiças cozidas e defumadas produzidas entre janeiro a outubro de 2018

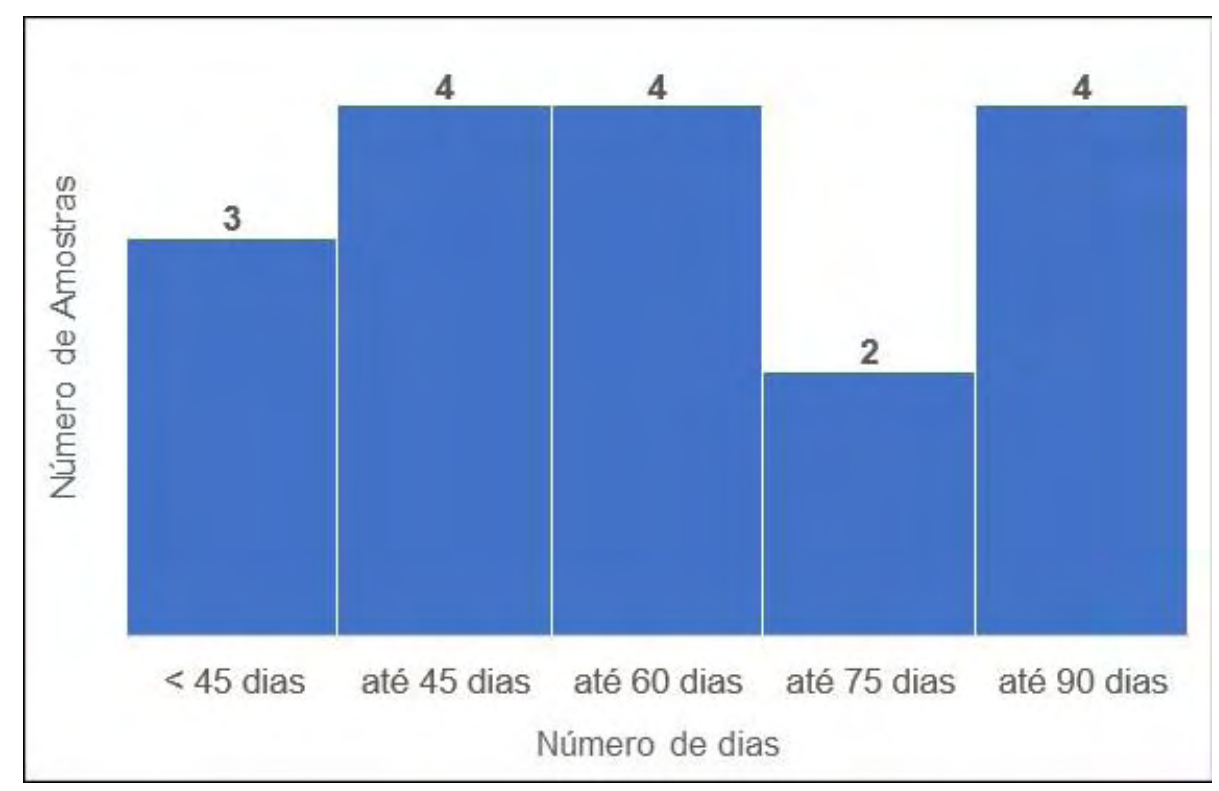

Estudo de Sukumaran et al. (2018) mostrou que a contagem total de mesófilos em salsicha cozida, embaladas a vácuo a $4^{\circ} \mathrm{C}$, aumentou de $2,03 \log \mathrm{UFC} / \mathrm{g}$ para 3,22 log UFC/g em 30 dias de armazenamento $(p=0,008)$. Porém, não houve aumento significativo dessa contagem até os 120 dias, o que pode ser explicado pelo crescimento de bactérias lácticas. Acima de 30 dias, bactérias do ácido lático atingiu de 3 a 4 log UFC/g de um nível não detectável no dia 0, resultando em declínio do pH e possível desenvolvimento de sabores como acidez.

Raimondi et al. (2018) avaliaram dez lotes de embutidos industrializados em atmosfera modificada $\left(\mathrm{CO}_{2} 30 \%, \mathrm{O}_{2} 70 \%\right)$. Durante a vida útil, o $\mathrm{pH}$ diminuiu para o acúmulo de ácidos acético e láctico. Ao longo da vida de prateleira, as bactérias aeróbias aumentaram de 4,7 log para 6,6 log UFC/g, e bactérias lácticas de 3,7 para $8,1 \log$ UFC/g. 
Drosinos et al. (2005), estudaram a flora microbiana de linguiças naturalmente fermentadas. As bactérias do ácido láctico foram as espécies dominantes no final da fermentação em todos os 3 lotes, com contagens próximas a $8 \mathrm{log}$ UFC/g. Os valores encontrados por Dias et al. (2013), para a contagem de bactérias do ácido láctico foram ao nível de 5 log UFC/g, em estudos para verificar a deterioração em linguiças frescas da carne de porco durante o armazenamento a temperaturas de $4^{\circ} \mathrm{C}$, foram observados também diminuição nos valores de $\mathrm{pH}$.

$\mathrm{O}$ desenvolvimento de bactérias lácticas diminuiu o $\mathrm{pH}$, caracterizando odor ácido, também indicativo de sabor ácido, além de perda de qualidade na aparência: presença de mela e líquido turvo. O rápido crescimento de bactérias lácticas, já aos 45 dias de armazenamento, pode estar associado à sua característica anaeróbia, e a maior competitividade em comparação a outras bactérias para produtos com embalagens à vácuo, conforme observado no estudo de Li et al. (2019).

No geral, segundo Pothakos et al. (2014), as bactérias do ácido láctico (BAL) não mostram afinidade com um substrato de carnes específico, mas geralmente resistente aos métodos de preservação atualmente implementados para que eles demonstrem tolerância. Ainda assim, a diversidade natural de BAL é considerada vasta entre espécies, subespécies e estirpes, uma vez que ecossistemas alimentares ou ambientais propaga a adaptação a diferentes condições. No entanto, pode haver uma distinção entre o clima frio, mesófilos e espécies estritamente psicrotróficas baseadas na faixa de temperatura eles proliferam.

\subsection{Conclusão}

Muitos alimentos deterioram devido à degradação microbiana com seus metabolitos sendo a causa de alterações aparência ou dos sabores desagradáveis ou off-flavour, resultando em rejeição sensorial, precisamente o que foi observado nestes estudos de shelf life: os principais atributos de recusa estavam diretamente relacionados aos produtos do metabolismo característico das bactérias ácido láticas.

Porém, apenas uma fração dessas bactérias presentes nas linguiças cozidas são responsáveis pela deterioração. Essas espécies não são conhecidas e muito trabalho é necessário para identificar os organismos de deterioração. 


\section{Referências}

1. DIAS, F. S.; RAMOS, C. L.; SCHWAN, R. F. Characterization of spoilage bacteria in pork sausage by PCR-DGGE analysis. Food Science and Technology, v. 33(3), p.468-474, 2013.

2. DROSINOS, E. H., MATARAGAS, M., XIRAPHI, N., MOSCHONAS, G., GAITIS, F.; METAXOPULOS, J. Characterisation of the microbial flora from a traditional Greek fermented sausage. Meat Science, 69, 307-317. 2005.

3. DUTCOSKY, S. D. Análise Sensorial de Alimentos. Curitiba: APC, 4a‥Ed.,540p. 2015.

4. GRAM, L.; RAVN, L.; RASCH, M.; BRUHN, J. B.; CHRISTENSEN, A. B.; GIVSKOV, M. Food spoilage-interactions between food spoilage bacteria International Journal of Food Microbiology, v. 78. p. 79- 97. 2002.

5. LI, X. et al. Changes in the microbial communities in vacuum-packaged smoked bacon during storage Food Microbiology. v. 77, p. 26-37, 2019.

6. NOOR, S., RADHAKRISHNAN, N. S.; HUSSAIN, K. Sausage formulations and effects of addition of different non-meat ingredients on sausages - a review. International Journal of Livestock Research, v. 6(12), p. 1-19. 2016

7. POTHAKOS, V.; DEVLIEGHERE, F.; VILLANI, F.; BJÖRKROTH, J.; ERCOLINI, D. Lactic acid bacteria and their controversial role in fresh meat spoilage. Meat Science, v. 109. p. 66-74. 2015.

8. POTHAKOS, V.; NYAMBI, C.; ZHANG, B.; PAPASTERGIADIS, A.; DE MEULENAER, B.; DEVLIEGHERE, F. Spoilage potential of psychrotrophic lactic acid bacteria (LAB) species: Leuconostoc gelidum subsp. gasicomitatum and Lactococcus piscium, on sweet bell pepper (SBP) simulation medium under different gas compositions. International Journal of Food Microbiology, v. 178, p. 120-129. 2014.

9. RAIMONDI, S. et al. Bacterial community of industrial raw sausage packaged in modified atmosphere throughout the shelf life International. Journal of Food Microbiology, v. 280, pp.78-86, 2018.

10. SILVA, N.; JUNQUEIRA, V. C. A.; SILVEIRA, N. F. A. et al. Manual de Métodos de Análise Microbiológica de Alimentos e Água. In: . Contagem total de microrganismos aeróbios mesófilos e psicotróficos em placas. 5. ed. São Paulo: Blucher, 2017. cap. 6, p.73-86. 
11.SUKUMARAN, A. T.; HOLTCAMP, A. J.; ENGLISHBEY, A. K. et al. Effect of deboning time on the growth of Samonella, E. coli, aerobic, and lactic acid bacteria during beef sausage processing and storage. Meat Science, v. 139. P. 49-55. 2018. 
CAPÍTULO 5 


\section{CAPÍTULO 5: CONSIDERAÇÕES E CONCLUSÃO FINAIS}

\subsection{Considerações finais}

Os produtos de carne devem conter obstáculos suficientes para inibir o crescimento de microrganismos patogênicos ou deteriorantes. O processamento térmico é ainda um dos métodos mais eficazes para a inativação de microrganismos indesejáveis nos alimentos. O calor é usado para inativar patógenos e desenvolver sabores, aromas, textura e cor típicos de um alimento cozido. A pasteurização produz alimentos mais seguros com maior prazo de validade. Como temperaturas amenas são aplicadas por um tempo determinado, técnicas complementares de conservação de alimentos, como atmosferas modificadas, adição de conservantes ou o uso de armazenamento e distribuição refrigerados, podem ser necessárias para controlar o crescimento dos microrganismos sobreviventes (Silva, 2012).

No Capítulo 2 concluímos que o cozimento das linguiças é eficiente uma vez que há redução significativa entre as etapas antes e após cozimento além disso, os valores encontrados para contagem total de mesófilos após o cozimento são semelhantes aos encontrados por outros autores. Outra observação importante é quanto à qualidade das matérias-primas utilizadas, já que a contagem total de mesófilos dos gomos antes do cozimento foi semelhante aos indicados pelos pesquisadores para a contagem total de mesófilos para a carne crua, ou seja, a matéria-prima não contribuiu para o aumento da carga microbiológica da massa da linguiça.

No Capítulo 3, com o auxílio de ferramentas da qualidade, foram avaliados os parâmetros físico-químicos do produto em estudo e observou-se que atendem à legislação, porém, os valores de aw e pH não são suficientes para inibir o desenvolvimento microbiano.

No Capítulo 4, concluímos que a deterioração das linguiças cozidas está ocorrendo pelo desenvolvimento das bactérias ácido láticas, desenvolvendo odor ácido, aparência de mela e líquido esbranquiçado.

Com esses estudos, concluímos que são utilizadas matérias-primas de boa qualidade e a etapa de cozimento é eficiente porém, considerando o cozimento uma etapa de pasteurização e não de esterilização, ainda permanecem algumas células viáveis após essa etapa e verifica-se que as barreiras deste produto não são suficientes para inibir o desenvolvimento das células remanescentes e deve-se 
estudar barreiras adicionais para o aumento do shelf life das linguiças calabresas cozidas e defumadas.

Mudanças nas condições ambientais, por exemplo, pela redução do $\mathrm{pH}$, pode ser uma maneira para inibir o desenvolvimento das células remanescentes após a etapa de cozimento. Além disso, a concorrência para os nutrientes pode selecionar para os organismos mais capazes de eliminar os compostos limitantes. Diversos microrganismos importantes na deterioração do alimento têm tais habilidades antagônicas. As bactérias láticas são capazes de produzir uma série de substâncias antimicrobianas como o ácido lático, peróxido de hidrogênio, diacetil e outros ácidos orgânicos. Além desses produtos finais resultantes do metabolismo, algumas cepas são também capazes de sintetizar compostos antimicrobianos de origem proteica, denominados bacteriocinas (DEEGAN et al. 2006, GALVEZ et al. 2008).

Bacteriocinas são peptídeos antimicrobianos sintetizados nos ribossomos, tendo sido descrita uma grande diversidade de bacteriocinas, as quais diferem entre si quanto a composição de aminoácidos, biossíntese, transporte e modo de ação. Nos alimentos, as bacteriocinas podem ser encontradas naturalmente como produtos da microbiota normal ou introduzida (cultura starter ou probióticos). Devido às suas aplicabilidades frente a organismos patogênicos contaminantes em alimentos, vários estudos têm sido publicados, tornando o uso destes peptídeos uma alternativa aos conservantes químicos tradicionais (OGAKI et al., 2015). São bacteriocinas as nisinas, pediocinas, lacticinas, lactococinas, leuconocinas, plantaricinas, enterocinas, carnobacteriocinas, entre outras.

A nisina é um peptídeo antimicrobiano composto por 34 aminoácidos, foi primeiramente empregada em laticínios e, atualmente, possui capacidade reconhecida na segurança dos alimentos. Destaca-se por ter um vasto espectro inibitório contra bactérias gram-positivas, podendo prevenir o desenvolvimento de esporos bacterianos. É produzida em escala industrial a partir de certas linhagens Lactococcus lactis, pertencente ao grupo sorológico N. O seu modo de ação está principalmente ligado à membrana citoplasmática de alguns microrganismos suscetíveis. As bacteriocinas dissipam a força protomotiva, cessando a geração de ATP via fosforilação oxidativa (FORSYTHE, 2002).

Uma vez que este grupo de organismos inclui bactérias resistentes ao calor, a nisina tornou-se um conservante de alimentos amplamente utilizado porque 
pode manter ou mesmo prolongar a vida de prateleira de produtos tratados termicamente alimentos e contribuir para a sua segurança.

\subsection{Conclusão}

As principais causas de deterioração das linguiças cozidas defumadas produzidas pela empresa "A" são a própria composição e forma de comercialização do produto. Uma vez que possuem ambiente favorável, $\mathrm{pH}$ ótimo e temperatura favorável para o desenvolvimento microbiológico e são comercializados sem refrigeração. Assim, as barreiras utilizadas atualmente não são suficientes.

\subsection{Sugestões para trabalhos futuros}

Sugere-se para trabalhos futuros estabelecer uma avaliação utilizando a metodologia de Análise do Modo e Efeito de Falhas (FMEA - Failure Mode and Efect Analysis) para controle do produto final para inibir o desenvolvimento das bactérias ácido láticas e também identificação das cepas dessas bactérias. 


\section{Referências}

1. DEEGAN, L. H. COTTER, P. D.; HILL, C.; ROSS, P.; Bacteriocins: Biological tools for bio-preservation and shelf life extension, International Dairy Journal, $v$. 16, p. 1058-1071. 2006.

2. FORSYTHE, S. J. Microbiologia da Segurança Alimentar. Porto Alegre: Artmed, 2002.

3. GALVEZ, A.; LOPEZ, R. L.; ABRIOUEL, H.; VALDIVIA, E.; OMAR, N. B.; Application of Bacteriocins in the Control of Foodborne Pathogenic and Spoilage Bacteria. Critical Reviews in Biotechnology, v. 28, p. 125-152. 2008.

4. OGAKI, M. B.; FURLANETO, M. C.; MAIA, L. F. Revisão: Aspectos gerais das bacteriocinas. Braz. J. Food Technol., Campinas v. 18 (4), p. 267-276. 2015.

5. SILVA, F. V.; GIBBS, P. A. Thermal pasteurization requirements for the inactivation of Salmonella in foods. Food Research International, v. 45(2), p. 695-699. 2012. 